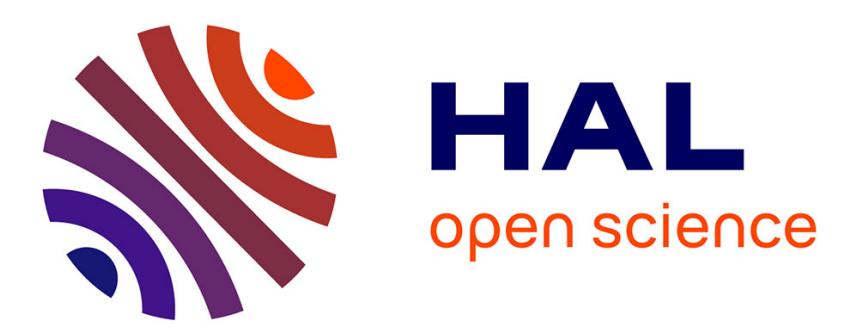

\title{
Low voltage-activated channels in rat pulmonary vein cardiomyocytes: coexistence of a non-selective cationic channel and of T-type Ca channels
}

\author{
Claire O Malécot
}

\section{- To cite this version:}

Claire O Malécot. Low voltage-activated channels in rat pulmonary vein cardiomyocytes: coexistence of a non-selective cationic channel and of T-type Ca channels. Pflügers Archiv European Journal of Physiology, 2020, 472, pp.1019 - 1029. 10.1007/s00424-020-02413-1 . hal-02881260

\section{HAL Id: hal-02881260 \\ https://hal.science/hal-02881260}

Submitted on 23 Dec 2020

HAL is a multi-disciplinary open access archive for the deposit and dissemination of scientific research documents, whether they are published or not. The documents may come from teaching and research institutions in France or abroad, or from public or private research centers.
L'archive ouverte pluridisciplinaire HAL, est destinée au dépôt et à la diffusion de documents scientifiques de niveau recherche, publiés ou non, émanant des établissements d'enseignement et de recherche français ou étrangers, des laboratoires publics ou privés. 


\section{Acknowledgement}

This is a post-peer-review, pre-copyedit version of an article published in Pflügers Archiv-European Journal of Physiology, 472, 1019-1029 (2020) - published online: June 18, 2020.

This file contains the main text and figures, as well as the supplementary material.

The final authenticated version is available online at: http://dx.doi.org/10.1007/s00424-020-02413-1 


\title{
Low voltage-activated channels in rat pulmonary vein cardiomyocytes: Coexistence of a non-selective cationic channel and of T-type Ca channels
}

\author{
Claire O. Malécot ${ }^{(1)}, \mathrm{PhD}$
}

(1) Centre National de la Recherche Scientifique

Université de Tours, Université de Poitiers, Laboratoire Signalisation et Transports Ioniques

Membranaires, EA 7349, 37200 Tours, France

Running title: LVA Ca currents in PV cardiomyocytes

Corresponding author:

Dr C.O. Malécot,

Laboratoire STIM, EA 7349, Université de Tours,

Faculté des Sciences, Parc de Grandmont,

37200 Tours, France

e-mail: claire.malecot@univ-tours.fr

ORCID ID: 0000-0003-4878-7810

Subject codes:

Basic Science Research; Ion Channels/Membrane Transport; Electrophysiology 


\section{ABSTRACT}

In rat pulmonary vein (PV) cardiomyocytes (CM), norepinephrine (NE) induces an automatic activity consisting of bursts of slow action potentials which depend on $\mathrm{Ca}^{2+}$ (upstroke) and $\mathrm{Na}^{+}$(inter-burst) channels. Our objective was to characterize low voltage-activated (LVA) currents in rat PVCM susceptible to trigger this activity. Whole-cell $\mathrm{I}_{\mathrm{Ca}}\left(5 \mathrm{mM} \mathrm{Ca}^{2+}\right)$ was recorded from $-100 \mathrm{mV}$ with classical $\mathrm{Na}^{+}$- and $\mathrm{K}^{+}$-free solutions. A fast LVA I $\mathrm{I}_{\mathrm{Ca}}\left(\mathrm{FLVA}-\mathrm{I}_{\mathrm{Ca}}\right)$, present in $\approx 56 \%$ of PVCM between $\sim-50$ to $-20 \mathrm{mV}$, was blocked by $10 \mu \mathrm{M} T \mathrm{TX}$ and markedly increased by addition of $\mathrm{NaCl}(1$ or $3 \mathrm{mM}$ ) or $\mathrm{KCl}$ ( 5 or $10 \mathrm{mM})$. Permeability ratios $\mathrm{P}^{\prime}{ }_{\mathrm{Ca}} / \mathrm{P}_{\mathrm{Na}}$ and $\mathrm{P}^{\prime}{ }_{\mathrm{Ca}} / \mathrm{P}_{\mathrm{K}}$ calculated for bi-ionic conditions were respectively $2.25 \pm 0.51$ and $1.88 \pm 0.25$, and not different from a value of 2 . FLVA-I $\mathrm{C}_{\mathrm{C}}$ was increased by $10 \mu \mathrm{M} N \mathrm{NE}$ and 300nM BayK8644, decreased by $5 \mu \mathrm{M}$ Nifedipine but not blocked by Ranolazine (10 $\mathrm{MM})$. $\mathrm{NiCl}_{2}(40 \mu \mathrm{M})$ and TTA-A2 (10 or 100nM) increased FLVA-I $\mathrm{Ca}_{\text {a }}$. Similar results were obtained in left atrial (LA) CM. Neither $\mathrm{Ba}^{2+}$ nor $\mathrm{Sr}^{2+}$ alone could permeate the FLVA channel or block $\mathrm{Ca}^{2+}$ influx but revealed a large slower activating and inactivating LVA Ca $^{2+}$ current (SLVA-I $\mathrm{C}_{\mathrm{Ca}}$ ), present in 10 out of $80 \mathrm{PVCM}$, absent in LACM, and partially inhibited by $100 \mathrm{nM}$ TTA-A2. Therefore, the ionic channel underlying FLVA-I $\mathrm{C}_{\mathrm{C}}$ is likely a fast voltage-gated non-selective channel with a dihydropyridine binding site. SLVA-I $\mathrm{I}_{\mathrm{Ca}} \mathrm{might}$ correspond to $\mathrm{Ca}^{2+}$ influx through $\mathrm{Ca}_{v} 3 . x$ channels and contribute to triggering NE-induced automatic activity in the PV myocardial sleeve.

KEYWORDS: Calcium channels, non-specific cationic channel, LVA currents

\section{NON-STANDARD ABBREVIATIONS AND ACRONYMS:}

CM, cardiomyocytes; FLVA, fast low voltage-activated; FSLVA, fast activating and slow inactivating low voltage-activated; $I_{\mathrm{Ca}}$, calcium current; $I_{\mathrm{Na}}$, sodium current LA, left atria; LVA, low voltageactivated; NE, norepinephrine; PV, pulmonary vein; SLVA, slow low voltage-activated; TTX, tetrodotoxin. 


\section{INTRODUCTION}

Ectopic activity arising from the pulmonary veins (PV) myocardial sleeve has been shown to play an important role in the onset of atrial fibrillation (AF) in humans [17]. However, although many studies were undertaken to decipher the underlying mechanism, none has succeeded so far and the question remains open [26]. In the rat, our laboratory has shown that application of the catecholamine norepinephrine (NE) induced an unusual automatic activity in PV myocardial sleeve, but not in the left atria (LA; [29]). This catecholaminergic automatic activity (CAA), which markedly differs from the classical cardiac pacemaker activity, consists of bursts of high frequency (4 to $5 \mathrm{~Hz}$ ) slow action potentials organized in a saw-tooth pattern [12]. In some way, this bursting activity looks similar to that of some hippocampal neurones for which T-type calcium channels have been found to noticeably contribute to their neuronal firing states (bursting and tonic; [7 for review, 8]). Like Cav1.3 channels, T-type Ca channels are also involved in cardiac automaticity as genetic inactivation of Ttype $\mathrm{Ca}_{\mathrm{v}} 3.1$ calcium channel in mice results in bradycardia and slowing of atrio-ventricular conduction (for review, [28, 31]).

The cellular electrophysiological characteristics of PV cardiomyocytes (CM) have been compared to those of atrial tissue in dog and several differences have been reported $[13,30]$. Concerning the T-type $\mathrm{Ca}^{2+}$ current, dog PV and LA CM were found to have identical current-voltage relationships (7 and 8 CM studied, respectively, [13]), but data on rat PV and LA CM are not available in the literature to our knowledge. Previous studies from our laboratory have shown contribution of extracellular calcium in the induction of CAA [6] as well as of TTX-sensitive sodium channels to the slope of slow depolarization between burst of CAA [27]. However, the trigger mechanism which should occur at relatively negative potentials [12] remains still unknown. If low (T-type) or medium $\left(\mathrm{Ca}_{v} 1.3\right)$ voltage-activated calcium channels were involved in triggering CAA, we hypothesized that rat PVCM should present a $\mathrm{Ca}^{2+}$ current different from that found in LACM, in terms of type or amplitude. Therefore, the objective of our study was to examine the properties of low voltage activated (LVA) $\mathrm{Ca}^{2+}$ currents in a large number of PV and LA CM. We report here that both rat PV and LA CM unexpectedly present a fast non-selective LVA cationic channel. Moreover, a large T-type $\mathrm{Ca}^{2+}$ current which was not observed in LACM was present in about $14 \%$ of PVCM. 


\section{METHODS}

Experiments were carried out on male Wistar rats (350-480g; CER Janvier, Le Genest St Isle, France. All protocols have been approved by the local ethical committee (Comité d'Ethique en Expérimentation Animale Val de Loire $\mathrm{n}^{\circ} 019$, Tours, France; approval reference number APAFIS\#6649-2016090711251954 v2) and conform to the guidelines from Directive 2010/63/EU of the European Parliament. Additional information is given in the Supplemental Material.

\section{Cardiomyocytes Isolation}

Cardiac myocytes were enzymatically (liberase plus protease) isolated as previously described $[27,34]$ at $37^{\circ} \mathrm{C}$ from the left and right superior pulmonary veins (PV) and left atria. All procedures are summarized in the Supplemental material. After isolation, isolated CM were kept in normal Tyrode solution (in mM: $140 \mathrm{NaCl}, 5.4 \mathrm{KCl}, 1 \mathrm{MgCl}_{2}, 1.36 \mathrm{CaCl}_{2}, 0.33 \mathrm{NaH}_{2} \mathrm{PO}_{4}, 10 \mathrm{HEPES}$ buffer and 11 glucose, $\mathrm{pH}$ adjusted to 7.4 with $\mathrm{NaOH}$ ) until use. Only cardiomyocytes presenting clear cut striations were used in this study. Therefore, they did not correspond to either vascular smooth muscle or endothelial cells that one would expect to find in the pulmonary vein (i.e, [11, 20, 21, 32].

\section{Patch-clamp recording of the calcium current $I_{c a}$}

The whole-cell recording configuration was used to study $I_{C a}$ at room temperature $\left(22-25^{\circ} \mathrm{C}\right.$; see Supplementary Material for details). The cell under study was directly superfused by gravity (small capillary - $300 \mu \mathrm{m}$ internal diameter - positioned within less than $20 \mu \mathrm{m}$ above the cell and allowing fast solution changes) with a solution containing (in mM): $144 \mathrm{TEACl}, 2$ or $5 \mathrm{CaCl}_{2}, 1 \mathrm{MgCl}_{2}, 5$ 4-aminopyridine, 10 HEPES buffer, and 11 glucose (pH 7.4 with TEAOH). The pipette solution contained (in mM): 115 DL-aspartic acid, 10 TEACl, $2 \mathrm{MgCl}_{2}, 10$ HEPES buffer, 10 EGTA, 5 Mg-ATP, and 5 diTris-phosphocreatine ( $\mathrm{pH} 7.25$ with $\mathrm{CsOH}$ leading to a final $\mathrm{Cs}^{+}$concentration of $137 \mathrm{mM}$ ).

Cells were continuously held at $-70 \mathrm{mV}$ (holding potential, HP) and activating pulses were preceded by a $200 \mathrm{~ms}$ hyperpolarising pulse to $-100 \mathrm{mV}$. The stimulation frequency was $0.2 \mathrm{~Hz}$. Membrane capacitance $\left(C_{m}\right)$ was calculated by integration of the capacitive currents in response to a series of 10 hyperpolarizing pulses applied from $-70 \mathrm{mV}$ (amplitude and duration: $10 \mathrm{mV}, 10 \mathrm{~ms}$ ) and then averaged. Calcium current amplitude was measured as peak inward current minus current flowing at the end of the 300 ms activating pulse, except when otherwise stated.

All data were normalised to the cell capacitance $C_{m}$ and are expressed as mean $\pm S E$ in $p A / p F$ or $\mathrm{nS} / \mathrm{pF}$ when quantified. 


\section{Patch-clamp recording of the fast sodium current $I_{N a}$}

The whole cell sodium current was recorded from a holding potential of $-110 \mathrm{mV}$ at room temperature in conditions where $\mathrm{K}^{+}$and $\mathrm{Ca}^{2+}$ currents were blocked, as previously described [27]. The extracellular solution contained (in mM): $110 \mathrm{TEACl}, 30 \mathrm{NaCl}, 1 \mathrm{CaCl}_{2}, 1 \mathrm{MgCl}_{2}, 2 \mathrm{CoCl}_{2} ; 0.1 \mathrm{GdCl}_{3}, 5$ aminopyridine, 10 HEPES buffer, and 11 glucose (pH 7.4 with TEAOH). The pipette solution contained (in mM): $110 \mathrm{CsCl}, 30 \mathrm{TEACl}, 7 \mathrm{NaCl}, 10$ HEPES buffer, 10 EGTA, and $5 \mathrm{Mg}$-ATP (pH 7.3 with CsOH).

\section{Relative permeability ratios and ion activities calculations}

Relative permeability ratios for $\mathrm{Ca}^{2+}$ over $\mathrm{Na}^{+}\left(\mathrm{P}^{\prime}{ }_{\mathrm{Ca}} / \mathrm{P}_{\mathrm{Na}}\right)$ or $\mathrm{K}^{+}\left(\mathrm{P}^{\prime}{ }_{\mathrm{Ca}} / \mathrm{P}_{\mathrm{K}}\right)$ were calculated from the shifts of the apparent reversal potential of the $\mathrm{Ca}^{2+}$ current induced by the addition of $\mathrm{Na}^{+}$or $\mathrm{K}^{+}$ to the extracellular solution, using a modified Goldman, Hodgkin and Katz equation (GHK) to take into account both divalent and monovalent ions, as described by Lewis [25]. Ion activity coefficients were calculated in each condition with the Davies equation S6 (see Supplementary Material for details).

\section{Chemicals and Reagents}

Chemicals were of reagent grade and obtained from Sigma-Aldrich (Saint Quentin Fallavier, France), Tocris, (R\&D Systems, Lille, France) and Alomone Labs Ltd, (Jerusalem, Israel). Reagents were prepared as $10^{-2} \mathrm{M}$ stock solutions in distilled water or DMSO, as needed, and kept frozen $\left(-20^{\circ} \mathrm{C}\right)$ until just prior to dilution in saline solutions.

\section{Statistics}

Data are presented as mean values $\pm \mathrm{SE}$, with the number of experiments indicated as $n$. Statistical significance was assessed with Mann-Whitney, Wilcoxon, Student's $t$-test or Fisher exact test where appropriate (SigmaStat V3.5, Systat Software Inc., Point Richmond, CA, USA). A P $<0.05$ value was considered to be significant. 


\section{RESULTS}

In pulmonary vein cardiomyocytes (PVCM) held at a negative potential in $\mathrm{Na}^{+}$and $\mathrm{K}^{+}$-free extracellular solution containing 2 or $5 \mathrm{mM} \mathrm{Ca}^{2+}$, several types of $\mathrm{Ca}^{2+}$ current could be activated by relatively small depolarizations. They could be distinguished by their kinetics: either very fast (FLVA, Fig. 1a1) or slow activating (SLVA, Fig. 1a2) and inactivating currents, or a mixture of both fast activating and slow inactivating current (FSLVA, Fig. 1a3). As a consequence, three types of current-

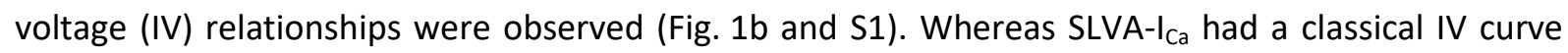
(open circles in Figs. $1 \mathrm{~b}$ and S1a), that of FLVA-I $\mathrm{Ca}_{\text {a }}$ (filled triangles) presented an unusual shape: peak current density was maximum at around $-35 \mathrm{mV}$, decreased between -25 to $-20 \mathrm{mV}$ and finally increased for more positive potentials. This is a characteristic of the IV curve of the TTX-sensitive calcium current, $I_{C_{a}(T \mathrm{TX})}$ (see discussion). The third type of IV curve (filled circles), typical of the presence of a T-type $\mathrm{Ca}^{2+}$ current, was found in only a minority of PVCM: 21 out of $148 \mathrm{CM}$ in the presence of $2 \mathrm{mM} \mathrm{Ca}^{2+}$ and 10 out of $99 \mathrm{CM}$ in the presence of $5 \mathrm{mM}$. In left atrial (LA) CM, FLVA-I Ca could also be recorded (Fig. S1b), but the T-type $\mathrm{Ca}^{2+}$ current, if present, was quite small (filled circles in Fig. S1b). The aim of the following experiments was to characterize these three low voltageactivated currents components in PVCM.

\section{Characteristics of the fast LVA current in PVCM}

In 2 mM extracellular $\mathrm{Ca}^{2+}$, the fast $\mathrm{LVA} \mathrm{Ca}^{2+}$ current (FLVA-I $\mathrm{Ca}$ ) was observed in 63 out of 148 PVCM. It was activated in a narrow range of low negative voltages between $\approx-55$ to $-30 \mathrm{mV}$. Its amplitude was relatively small $(\approx-0.6 \mathrm{pA} / \mathrm{pF})$, representing $\approx 13 \%$ of maximum peak $\mathrm{Ca}^{2+}$ current recorded at $+15 \mathrm{mV}\left(\mathrm{I}_{\text {Camax }}\right.$; Table 1 and Fig S1a). In $19 \mathrm{CM}$ with no apparent FLVA-I $\mathrm{I}_{\mathrm{Ca}}$ in $2 \mathrm{mM} \mathrm{Ca}^{2+}$, increasing the extracellular $\mathrm{Ca}^{2+}$ concentration to $5 \mathrm{mM}$ revealed its presence in 14 of them. In another set of experiments in the direct presence of $5 \mathrm{mM}$ extracellular $\mathrm{Ca}^{2+}, \mathrm{FLVA}^{\mathrm{I}} \mathrm{Ca}_{\mathrm{a}}$ was found in 45 out of 80 PVCM (Fig. 1a1 and b). Thus, FLVA-I Ca $_{\text {a }}$ was not present in all PVCM, unlike the classical Ltype current. Compared with data recorded with $2 \mathrm{mM} \mathrm{Ca}^{2+}$, in $5 \mathrm{mM} \mathrm{Ca}^{2+}$ the peak current voltage was $\approx 6 \mathrm{mV}$ more positive and its amplitude was larger $(\approx 2.5 \mathrm{fold})$ as well as its ratio to $\mathrm{I}_{\text {camax }}$ recorded at $+20 \mathrm{mV}(\approx 2$ fold; Table 1$)$. The apparent reversal potential was $\approx 11.3 \mathrm{mV}$ positively shifted, as expected for a current carried only by $\mathrm{Ca}^{2+}$ (theoretical shift of $11.7 \mathrm{mV}$ at $25^{\circ} \mathrm{C}$ ). Neither the peak current amplitude nor its ratio to $\mathrm{I}_{\text {Camax }}$ depended on the CM size approximated by its membrane capacitance in both conditions (Fig. S2). There was also no correlation between peak 
FLVA-I $\mathrm{I}_{\mathrm{Ca}}$ and $\mathrm{I}_{\mathrm{Camax}}$ density. FLVA-I $\mathrm{C}_{\mathrm{Ca}}$ was also found in 50 out of 79 LACM in $2 \mathrm{mM} \mathrm{Ca}^{2+}$. Its activation threshold, peak voltage and apparent reversal potential were not significantly different but its amplitude was smaller than in PVCM (Table 1 and Fig. S1b). In both PV and LA CM, the presence of FLVA-I $\mathrm{Ca}_{\mathrm{a}}$ could not be ascribed to a specific CM phenotype.

Steady-state availability of the current was determined with a classical double-pulse voltageclamp protocol (Fig.S3) . In the presence of $5 \mathrm{mM}$ extracellular $\mathrm{Ca}^{2+}$, the availability curve determined with a test potential to $-40 \mathrm{mV}$ ( maximum FLVA current amplitude) was best described with a double Boltzmann equation in 4 out of 6 PVCM and a single Boltzmann in the two others. As there was no difference in the half inactivation voltages $V_{0.5}$ of the more negative component between the two groups of cells, values were pooled. In these conditions, the mean $V_{0.5}$ values were $-85.57 \pm 0.90$ $m V(n=6)$ and $-65.31 \pm 2.19 m V(n=4)$, with respective slope factors of $-4.38 \pm 0.23 m V$ and $-8.00 \pm$ $0.70 \mathrm{mV}$ (Fig. S3). When present, the less negative component accounted for $21.89 \pm 7.56 \%$ of the total current at $-40 \mathrm{mV}$. These results suggest either that FLVA-I $\mathrm{Ca}_{\mathrm{a}}$ presented two voltage-dependent inactivating components or that a second smaller $\mathrm{Ca}^{2+}$ current, with less negative $\mathrm{V}_{0.5}$, was concurrently activated during the test pulse to $-40 \mathrm{mV}$ (see below).

Figure 2a1 shows that FLVA-I $\mathrm{I}_{\mathrm{Ca}}$ was entirely blocked by $10 \mu \mathrm{M}$ TTX over the whole range where the current could be recorded (Fig. 2a3). Thus, it might correspond to the TTX-sensitive

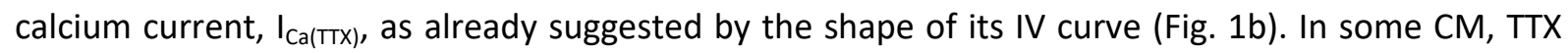
application unveiled a slower activating and inactivating calcium current component (Fig. 2a2). Ranolazine, another $\mathrm{Na}^{+}$channel blocker, had no effect at $10 \mu \mathrm{M}$ (Fig. 2b and Table S2), a concentration that we have shown to block $28 \%$ of the fast $\mathrm{Na}_{v} 1.5$ current in rat PVCM [27].

\section{FLVA channel permeability to divalent cations}

Figure 3a shows that removal of external $\mathrm{Ca}^{2+}$ completely suppressed FLVA-I $\mathrm{I}_{\mathrm{C}}$, thus confirming its $\mathrm{Ca}^{2+}$ nature, as already suggested by the shift of its apparent reversal potential when the extracellular $\mathrm{Ca}^{2+}$ concentration was increased from 2 to $5 \mathrm{mM}$. If the FLVA channel was a $\mathrm{Ca}^{2+}$ selective ion channel, then the classical $\mathrm{Ca}^{2+}$ substituting ions should also permeate the channel and give rise to a sizable current. As shown in Fig. $3 \mathrm{~b}$ and $3 \mathrm{c} 1$, equimolar substitution of $\mathrm{Ca}^{2+}$ by $\mathrm{Sr}^{2+}$ or $\mathrm{Ba}^{2+}$ entirely suppressed the fast current( $\mathrm{n}=6$ and 10 , respectively). In some $\mathrm{CM}$, a small slower activating and inactivating current component remained in the presence of $\mathrm{Ba}^{2+}$ (Fig. $3 \mathrm{c} 2$ ) or $\mathrm{Sr}^{2+}$, suggesting that it might correspond to a T-type $\mathrm{Ca}^{2+}$ current. Thus, FLVA-I $\mathrm{Ca}_{\mathrm{a}}$ and T-type $\mathrm{Ca}^{2+}$ current could be simultaneously present and/or activated in some PVCM (see also Fig. 2a2). 


\section{The FLVA channel is a non-selective cationic channel: permeability to monovalent cations}

The negative apparent reversal potential and voltage range of activation of the FLVA current suggested that the underlying channel might be non-selective for $\mathrm{Ca}^{2+}$. Therefore, we next examined whether monovalent cations naturally present in blood or physiological solutions could permeate the channel in the presence of $\mathrm{Ca}^{2+}$. Figures $4 \mathrm{a}$ and $4 \mathrm{~b}$ respectively illustrate that the addition of either $\mathrm{Na}^{+}(1$ and $3 \mathrm{mM})$ or $\mathrm{K}^{+}(5$ and $10 \mathrm{mM})$ to the extracellular medium actually increased FLVA current. As shown Fig. S4, it should be noted that, for a given monovalent ion concentration, increase of the current amplitude was greater with $\mathrm{Na}^{+}$than with $\mathrm{K}^{+}$. Shifts of the apparent reversal potentials of the currents induced by increasing either $\mathrm{Na}^{+}$or $\mathrm{K}^{+}$concentrations ( $\mathrm{Na}^{+}$from 1 to $3 \mathrm{mM}: \approx 13 \mathrm{mV}$ and $\mathrm{K}^{+}$ from 5 to $10 \mathrm{mM}: \approx 6 \mathrm{mV}$ ) in the presence of $5 \mathrm{mM} \mathrm{Ca}^{2+}$ were much less than expected for a current carried only by $\mathrm{Na}^{+}$or $\mathrm{K}^{+}$(Table S1; theoretical shifts of $28.2 \mathrm{mV}$ and $17.8 \mathrm{mV}$ at $25^{\circ} \mathrm{C}$, respectively), thus suggesting that $\mathrm{Ca}^{2+}$ and $\mathrm{Na}^{+}$or $\mathrm{K}^{+}$can simultaneously flow through the channel. Monovalent cations alone could also permeate the channel as shown Fig. $4 c$ for $\mathrm{K}^{+}$. In these experiments, when 5 $\mathrm{mM} \mathrm{Ca}{ }^{2+}$ was replaced by equimolar $\mathrm{Mg}^{2+}$ to keep the divalent ions concentration constant, the current recorded in the presence of both $\mathrm{Ca}^{2+}$ and $\mathrm{K}^{+}$was rapidly reduced and only an inward current carried by $\mathrm{K}^{+}$remained $(n=8)$. This current was similar in amplitude to that carried by $\mathrm{Ca}^{2+}$ alone.

The relative permeability for $\mathrm{Ca}^{2+}$ over $\mathrm{Na}^{+}$or $\mathrm{K}^{+}$were therefore calculated using a modified GHK equation for bi-ionic conditions (see Supplementary Material) to take into account the presence of the divalent cation $\mathrm{Ca}^{2+} . \mathrm{P}^{\prime}{ }_{\mathrm{Ca}} / \mathrm{P}_{\mathrm{K}}$ values were not significantly different when calculated from the shift of the apparent reversal potential (see Supplementary Material) induced by the addition of either 5 or $10 \mathrm{mM} \mathrm{KCl}$ (respectively: $1.944 \pm 0.447$ and $1.812 \pm 0.299, \mathrm{n}=7$ for each; Table S1; MannWhitney rank sum test, $\mathrm{P}=0.795)$. Therefore, when all values were pooled, the mean $\mathrm{P}^{\prime}{ }_{\mathrm{C}} / \mathrm{P}_{\mathrm{K}}$ was equal to $1.878 \pm 0.249(n=14)$. The relative permeability $\mathrm{P}^{\prime}{ }_{\mathrm{Ca}} / \mathrm{P}_{\mathrm{Na}}$ calculated after adding $1 \mathrm{mM} \mathrm{NaCl}$ amounted to $2.254 \pm 0.508(n=6)$, and was not significantly different from the calculated $\mathrm{P}^{\prime}{ }_{\mathrm{C} a} / \mathrm{P}_{\mathrm{K}}$ (Mann-Whitney rank sum test, $\mathrm{P}=0.483$ ). Both values were not significantly different from a value of 2 (z-test; $\mathrm{P}=0.291$ for $\mathrm{P}^{\prime}{ }_{\mathrm{Ca}} / \mathrm{P}_{\mathrm{Na}}$ and 0.694 for $\mathrm{P}^{\prime}{ }_{\mathrm{C} a} / \mathrm{P}_{\mathrm{K}}$ ). Thus, $\mathrm{P}^{\prime}{ }_{\mathrm{Ca}} / \mathrm{P}_{\mathrm{K}}=\mathrm{P}^{\prime}{ }_{\mathrm{Ca}} / \mathrm{P}_{\mathrm{Na}} \approx 2$. It should be noted that in the presence of $3 \mathrm{mM} \mathrm{Na}^{+}, \mathrm{P}^{\prime}{ }_{\mathrm{Ca}} / \mathrm{P}_{\mathrm{Na}}$ markedly decreased to $\approx 0.2$ (Table S1), likely because of $\mathrm{Na}^{+}$flow through the fast $\mathrm{Na}_{\mathrm{v}} 1.5$ channel whose activation voltage overlaps with that of FLVA.

Channel conductance in the presence of $5 \mathrm{mM} \mathrm{Ca}^{2+}$ alone (control conditions) or $5 \mathrm{mM} \mathrm{Ca}^{2+}$ plus $\mathrm{Na}^{+}$or $\mathrm{K}^{+}$were calculated from the peak currents and apparent reversal potentials for each $\mathrm{CM}$, 
as described in the Supplementary Material (Eq. S2). In control conditions and with $1 \mathrm{mM} \mathrm{NaCl}$ added (Fig. 5a), single Boltzmann functions were sufficient to best describe the conductance (control: $\mathrm{V}_{0.5}$ of $-39.86 \pm 2.90 \mathrm{mV}$ with $\mathrm{k}=2.72 \pm 0.24 \mathrm{mV}, \mathrm{n}=5 ;+1 \mathrm{mM} \mathrm{NaCl}: \mathrm{V}_{0.5}$ of $-40.85 \pm 1.32 \mathrm{mV}$, with $k=3.62 \pm 0.23 \mathrm{mV}, \mathrm{n}=5 ; \mathrm{P}<0.05$ for $\mathrm{k}$ values). However, a double Boltzmann function was necessary with $3 \mathrm{mM} \mathrm{NaCl}$ added (respectively, $\mathrm{V}_{0.5}$ of $-44.01 \pm 1.84 \mathrm{mV}$ and $-32.87 \pm 2.48 \mathrm{mV}$, $\mathrm{k}$ values of $3.05 \pm$ $0.12 \mathrm{mV}$ and $3.44 \pm 0.53 \mathrm{mV}$, and amplitudes of $0.37 \pm 0.04 \mathrm{nS} / \mathrm{pF}$ and $0.12 \pm 0.02 \mathrm{nS} / \mathrm{pF}, \mathrm{n}=5$ ), likely because of the overlap of $\mathrm{Na}_{v} 1.5$ and FLVA channels activation voltages. On the contrary, in control conditions and in the additional presence of either 5 or $10 \mathrm{mM} \mathrm{KCl}$, channel conductance was always best described with a single Boltzmann function (Fig. 5b) with respective $V_{0.5}$ of $-44.15 \pm 1.56$ $m V,-41.33 \pm 1.75 \mathrm{mV}$ and $-43.88 \pm 1.97 \mathrm{mV}(\mathrm{n}=8)$. Only $\mathrm{k}$ values were significantly different from control (respectively: $2.51 \pm 0.12 \mathrm{mV}, 4.35 \pm 0.16 \mathrm{mV}$ and $3.91 \pm 0.24 \mathrm{mV}$ ).

Figure $5 c$ shows that the main negative component of channel conductance $\left(\mathrm{V}_{0.5}\right.$ around --40 to $-45 \mathrm{mV}$ ) saturated for added monovalent concentration as low as $5 \mathrm{mM}$. From the Langmuir isotherm $\left(Y=Y_{\max } /\left(1+\left(K_{D} /[\text { lon }]\right)^{p}\right)\right.$ adjusted to the mean data points, a $K_{D}$ value of $0.78 \mathrm{mM}$ with $\mathrm{p}=1.24$ could be determined as well as a maximum total conductance of $0.43 \mathrm{nS} / \mathrm{pF}$ in the presence of $5 \mathrm{mM} \mathrm{Ca}^{2+}$ and either $\mathrm{Na}^{+}$or $\mathrm{K}^{+}$.

\section{Activation and inactivation kinetics of FLVA and fast $\mathrm{Na}$ current $I_{\mathrm{Na}}$}

To determine whether FLVA-I $\mathrm{Ca}$ might just correspond to $\mathrm{Ca}^{2+}$ flowing through fast $\mathrm{Na}^{+}$ channels since there is overlap of their activation voltage ranges, their kinetics of activation and inactivation were compared. As shown in Fig. S5a1, activation of FLVA-I $\mathrm{Ca}_{\mathrm{a}}$ assessed by its time to peak $(n=14)$ was significantly slower than that of $I_{N a}(n=12)$ at all voltages. Inactivation time course of $I_{\mathrm{Na}}$ was best described by the sum of two exponentials whose time constant voltage relationships are shown in Fig. S5a2. The major component of $I_{\mathrm{Na}}$ was also the faster. On the contrary, the FLVA current had a mono exponential decay at all voltages. The inactivation rate of FLVA-I $\mathrm{Ca}_{\mathrm{Ca}}$ lay between those of $I_{N a}$ as shown in Fig. S4a2. The addition of either $\mathrm{Na}^{+}$or $\mathrm{K}^{+}$did not significantly modify the time to peak current (Fig. S5b1) or decay time constants (Fig. S4b2). Although these parameters values were slightly decreased, they remained statistically different from those of $I_{\mathrm{Na}}$. 


\section{Pharmacological characterization of the FLVA channel}

The pharmacological data presented in Table S2 and Fig. 6 show that beside its inhibition by TTX, FLVA-I Ca was sensitive to dihydropyridines, being markedly reduced by $5 \mu \mathrm{M}$ nifedipine (L-type Ca channel blocker; Fig.6a) and increased by 300 nM ( \pm )-BayK 8644 (L-type Ca channel activator; Fig. $6 b)$. On the other hand, it was not reduced by $200 \mathrm{nM}(+)$-cis-diltiazem, a benzothiazepine derivative $\mathrm{Ca}^{2+}$ channel blocker $(n=6)$. Norepinephrine $(10 \mu \mathrm{M})$ also increased the current (Table S2), an effect being reversed by $5 \mu \mathrm{M}$ atenolol. Cirazoline $(1 \mu \mathrm{M})$, a specific $\alpha_{1}$-adrenergic agonist, had no effect on the current $(n=5)$. All these effects were reversible upon washout.

\section{Multiple components of LVA $\mathrm{Ca}^{2+}$ current in rat PVCM}

Study of the steady-state availability of the FLVA determined with a test pulse to $-40 \mathrm{mV}$ has revealed the possible existence of the simultaneous activation of a second type of $\mathrm{Ca}^{2+}$ current representing about $20 \%$ of the total current with a less negative half inactivation voltage $V_{0.5 \cdot}(\sim-65$ $\mathrm{mV}$ compared to $\sim-85 \mathrm{mV}$; Fig. S3). To confirm the presence of this current, we used a test pulse of $-25 \mathrm{mV}$, close to FLVA apparent reversal potential. Two Boltzmann functions were still necessary to best describe the current availability (Fig. S3). The main component, representing about $92 \%$ of the total current, had a mean $V_{0.5}$. value of $-69.34 \pm 0.14 \mathrm{mV}(n=4)$ which was not statistically different from that of the small component found with the test pulse of $-40 \mathrm{mV}$. These $V_{0.5}$.values are those expected for T-type $\mathrm{Ca}^{2+}$ channels. The minor component, with a mean $\mathrm{V}_{0.5}$. value of $-26.73 \pm 3.20 \mathrm{mV}$ $(n=4)$ corresponded to activation of L-type $\mathrm{Ca}^{2+}$ channels, as shown with a test pulse to $+15 \mathrm{mV}$ (mean $\mathrm{V}_{0.5}$. values of $-66.78 \pm 1.44 \mathrm{mV}$ and $-24.38 \pm 1.16 \mathrm{mV}(\mathrm{n}=10)$ for the small and major components, respectively; Fig.S3). Similar results were also obtained in LACM. No current component with a mid-inactivation voltage compatible with that of $\mathrm{Ca}_{\mathrm{v}} 1.3$ channel ( $\sim-40$ to $-45 \mathrm{mV}$; [28]) could be isolated.

To test whether the $\mathrm{Ca}^{2+}$ current which overlapped with the non-selective cationic FLVA current was indeed a T-type $\mathrm{Ca}^{2+}$ current, as suggested by the $\mathrm{V}_{0.5}$.values of the steady-state inactivation curves, we used two reportedly specific blockers of $\mathrm{Ca}_{v} 3.1$ and $\mathrm{Ca}_{\mathrm{v}} 3.2$. Surprisingly, FLVA$\mathrm{I}_{\mathrm{Ca}}$ was significantly increased by TTA-A2 (10 nM, n=11 and $100 \mathrm{nM}, \mathrm{n}=6$ - Table S2 and Fig. 6c) and $\mathrm{NiCl}_{2}(40 \mu \mathrm{M}, \mathrm{n}=9$, Table S2 and Fig. 6d). Similar results were also obtained in LACM (not shown). Nevertheless, although the number of PVCM presenting a marked shoulder in their current-voltage (IV) relationships at negative potentials (maximum around $-25 \mathrm{mV}$; see Fig. 1b, filled circles and Fig. S6) is quite low, we were able to apply 100 nM TTA-A2 to two such PVCM. Fig. S6 shows that TTA-A2 significantly reduced the shoulder amplitude at $-25 \mathrm{mV}$, suggesting the effective presence of an 
underlying T-type $\mathrm{Ca}^{2+}$ current. The $\mathrm{Ca}^{2+}$ current was also markedly reduced by $40 \mu \mathrm{M} \mathrm{NiCl}_{2}(-84.0 \pm$ $4.5 \%$ and $-78.6 \pm 4.8 \%$ at $-25 \mathrm{mV}$ and $+15 \mathrm{mV}$, respectively, $\mathrm{n}=9$ ).

To confirm the presence of $\mathrm{Ca}_{v} 3 . x$ T-type $\mathrm{Ca}^{2+}$ current in PVCM, besides the TTX-sensitive FLVA-I $\mathrm{Ca}_{\mathrm{a}}$, currents recorded with $200 \mathrm{~ms}$ pre-pulses to $-40 \mathrm{mV}$ were subtracted from the whole $\mathrm{Ca}^{2+}$ current recorded from -100 mV in the same cells. In both PV and LA CM, three groups of CM were first visually distinguished on the basis of the shape of their IV curve from $-100 \mathrm{mV}$ (see Fig. 1b), before subtraction. Figure 7 shows that the IV curves of the $-40 \mathrm{mV}$ pre-pulse difference currents markedly differ in PV (Fig. 7a) and LA (Fig. 7b) CM. In PVCM, a small voltage-dependent pre-pulsesensitive $\mathrm{Ca}^{2+}$ current could be recorded positive to $-50 \mathrm{mV}$ (Fig. 7a, open circles). As expected from its inactivation curve, FLVA-I $\mathrm{Ca}_{\mathrm{a}}$ was sensitive to the $-40 \mathrm{mV}$ pre-pulse and its IV relationship globally retained its "V"shape (filled triangles). These currents were much smaller in LACM (Fig. 7b). Finally, a large prepulse-sensitive current was present in PVCM which presented a shoulder in their $-100 \mathrm{mV} \mathrm{IV}$ curve (filled circles). This last current was barely detectable in LACM. Thus, three types of LVA Ca ${ }^{2+}$ currents exist among the PVCM population and are much larger than those found in the LACM population. 


\section{DISCUSSION}

Three principles points arise from this investigation. (1) Cardiomyocytes (CM) isolated from rat pulmonary vein (PV) and left atrium (LA) present a fast low voltage-activated non selective cationic current (carried by $\mathrm{Na}^{+}, \mathrm{K}^{+}$and $\mathrm{Ca}^{2+}$ ) which is sensitive to TTX and dihydropyridines. However, neither $\mathrm{Ba}^{2+}$ nor $\mathrm{Sr}^{2+}$ could substitute as permeant species for $\mathrm{Ca}^{2+}$. (2) A large T-type $\mathrm{Ca}^{2+}$ current was found in a subpopulation of rat PVCM but not in LACM. (3) There was no evidence for the presence of a $\mathrm{Ca}^{2+}$ current through $\mathrm{Ca}_{\mathrm{v}} 1.3$ channels.

A low voltage activated $\mathrm{Ca}^{2+}$ current blocked by $\operatorname{TTX}\left(\mathrm{I}_{\mathrm{Ca}(\mathrm{TTX})}\right)$ has been described in rat hippocampal CA1 neurones [2,39] and cardiac tissues from the ventricle of rat $[1,3,5,9,18,36]$, guinea-pig [10, 18], mouse [5, 40], and from human atrium [23] and ventricle [40]. To our knowledge, our study reports for the first time its existence in rat PVCM and LACM. The ionic nature of this current is still a matter of debate: a novel $\mathrm{Ca}^{2+}$ channel [23], a $\mathrm{Na}^{+}$channel distinct from $\mathrm{Na}_{v} 1.5[3,9]$, $\mathrm{Na}^{+}$channels permeant to $\mathrm{Ca}^{2+}[16,40]$.

Although blocked by $\Pi \mathrm{XX}$, the FLVA-I $\mathrm{I}_{\mathrm{Ca}}$ reported in our study markedly differs from $\mathrm{I}_{\mathrm{Ca}(T \mathrm{X})}$ described in human atrial cells [23] in that neither equimolar $\mathrm{Ba}^{2+}$ nor $\mathrm{Sr}^{2+}$ could substitute for $\mathrm{Ca}^{2+}$. However, $\mathrm{Ba}^{2+}$ was also found to be unable to replace $\mathrm{Ca}^{2+}$ in rat ventricular cells [16], as well as in HEK-293 cells expressing the cardiac $\mathrm{Na}_{v} 1.5$ channel (SCN5A; [16]), two preparations in which $\mathrm{I}_{\mathrm{Ca}(T \mathrm{X})}$ was present. In rat CA1 hippocampal neurones, replacement of $10 \mathrm{mM} \mathrm{Ca}^{2+}$ by equimolar $\mathrm{Sr}^{2+}$ and $\mathrm{Ba}^{2+}$ induced much smaller currents (amplitude ratio $\mathrm{Ca}^{2+}: \mathrm{Sr}^{2+}: \mathrm{Ba}^{2+}=1.00: 0.33: 0.005 ;[2]$ ). Because $\mathrm{Cs}^{+}$can permeate $\mathrm{I}_{\mathrm{Ca}(\mathrm{Tx})}$ channel $[9,16,40]$ and that our pipette solution was $\mathrm{Cs}^{+}$-based, we cannot exclude the possibility that a very small current carried by either $\mathrm{Sr}^{2+}$ or $\mathrm{Ba}^{2+}$ could have been masked by an overlapping outward $\mathrm{Cs}^{+}$current, though inspection of the current records (Fig. 3) makes this unlikely. FLVA-I $I_{\mathrm{Ca}}$ differs also from $\mathrm{I}_{\mathrm{Ca}(\mathrm{TTX})}$ found in guinea-pig ventricular cells [10] as it was sensitive to dihydropyridines. There again, FLVA-I $I_{C a}$ shared similitudes with $I_{C a(T x)}$ found in rat CA1 hippocampal neurones which are concentration-dependently inhibited by several dihydropyridines [39]. Thus, since the reported $\mathrm{I}_{\mathrm{Ca}(\mathrm{TTX})}$ properties seem to be tissue-dependent, it is not possible to affirm that FLVA-I $I_{C_{a}}$ is really $I_{C a(T T X)}$ but only that it shares some of its reported properties. Therefore, in this study, the term of FLVA current will be retained.

The negative apparent reversal potential of FLVA-I $\mathrm{I}_{\mathrm{Ca}}$ is in agreement with the non-selective nature of the channel. Indeed, we found that $\mathrm{Na}^{+}$or $\mathrm{K}^{+}$ions can simultaneously flow through FLVA channels with $\mathrm{Ca}^{2+}$ and that extracellular $\mathrm{K}^{+}$ions alone were also able to carry an inward current 
through the channel. All these observations are also in agreement with results for $\mathrm{I}_{\text {CaTTX}}$, showing that monovalent cations can also give rise to sizable currents, either inwardly $\left(\mathrm{Na}^{+}, \mathrm{Cs}^{+}\right)$or outwardly $\left(\mathrm{Cs}^{+}\right.$, $\left.\mathrm{K}^{+}\right)$directed $[1,2,9,16,40]$. However, since $\mathrm{K}^{+}$is only weakly permeant through $\mathrm{Na}^{+}$channels $\left(\mathrm{P}_{\mathrm{K}} / \mathrm{P}_{\mathrm{Na}}\right.$ $\sim 0.03$ to $0.08 ;[14,19,38], \mathrm{FLVA}_{\mathrm{Ca}}$ is unlikely to result from $\mathrm{Ca}^{2+}$ flow through classical $\mathrm{Na}^{+}$channels. Moreover, the FLVA current had slower activation and inactivation kinetics than $I_{\mathrm{Na}}$ even in the presence of $\mathrm{Na}^{+}$or $\mathrm{K}^{+}$.

To our knowledge, a FLVA channel permeant to $\mathrm{Ca}^{2+}, \mathrm{Na}^{+}$and $\mathrm{K}^{+}$giving rise to inward currents has not been reported in the literature. Thus, it would be tempting to classify this channel as a kind of voltage-gated transient receptor potential (TRP) channel, as it is now admitted that some of them present a voltage-dependent activation (for review, [33]). The fact that we found in our experimental conditions that $\mathrm{Ca}^{2+}$ was two times more permeant than $\mathrm{Na}^{+}$or $\mathrm{K}^{+}$suggests that the channel might derivate from a Ca ${ }^{2+}$ channel rather than from a $\mathrm{Na}^{+}$channel $[1,9,16,37,40]$. This hypothesis is also supported by the saturation of the channel conductance for monovalent cation concentrations as low as $5 \mathrm{mM}$. Another possibility would be that $\mathrm{Ca}^{2+}$ has partially blocked $\mathrm{Na}^{+}$and $\mathrm{K}^{+}$permeation through the channel.

Taking into account the screening effect of $\mathrm{Ca}^{2+}$, the mid-activation voltage $\left(\mathrm{V}_{0.5}\right)$ of FLVA conductance we determined in the presence of $5 \mathrm{mM} \mathrm{Ca}^{2+}(-42.3 \pm 1.5 \mathrm{mV}, \mathrm{n}=13)$ is similar to that of the negative ranolazine-sensitive component of $\mathrm{Na}^{+}$conductance we have found in PVCM in the presence of $1 \mathrm{mM} \mathrm{Ca}^{2+}$ ( -50 mV; [27]). Since we show here that $10 \mu \mathrm{M}$ ranolazine had no effect on FLVA-I ${ }_{C a}$, these results strongly suggest that two types of channels with identical mid voltage of activation, i.e., FLVA channels and ranolazine-sensitive $\mathrm{Na}_{v} 1.5$ channels, contribute to the negative component of $\mathrm{Na}^{+}$channel conductance we have found [27]. This hypothesis is also supported by the observation that currents recorded in the presence of both $\mathrm{Ca}^{2+}$ and $\mathrm{Na}^{+}$were larger than those in the presence of $\mathrm{Ca}^{2+}$ and $\mathrm{K}^{+}$. Indeed, if only one type of channel were involved, current amplitudes in the presence of additional $\mathrm{Na}^{+}$or $\mathrm{K}^{+}$should be identical for a given monovalent concentration since $\mathrm{Na}^{+}$and $\mathrm{K}^{+}$permeabilities through FLVA channels are identical and that both ions have the same activity coefficient in solution. These findings also support the idea that FLVA channels are not just $\mathrm{Na}_{\mathrm{v}} 1.5$ channels permeant to $\mathrm{Ca}^{2+}$ and $\mathrm{K}^{+}$.

After rupture of the membrane patch, we noticed that FLVA-I $\mathrm{Ca}_{\mathrm{a}}$ needed some time to appear (diffusion of the pipette solution into the cell) and to be stable in amplitude (not shown). Moreover, it was subject to use-dependent potentiation after a rest period, as found for $\mathrm{Na}_{\mathrm{v}} 1.6$ [41] and $\mathrm{Ca}^{2+}$ channels [15]. Taking into consideration these peculiarities during our experiments, we found that FLVA-I $\mathrm{Ca}_{\mathrm{a}}$ was nevertheless not present in all CM, and that it was more frequently found in LACM (in 
50 out of $79 \mathrm{CM}$ in the presence of $2 \mathrm{mM} \mathrm{Ca}^{2+}-63.3 \%$ ) than in PVCM (in 122 out of $228 \mathrm{CM}$ in the presence of either 2 or $5 \mathrm{mM} \mathrm{Ca}^{2+}-53.5 \%$ ). Lemaire et al [23] also found that $\mathrm{I}_{\mathrm{Ca}(\mathrm{TTX})}$ was present in only $40 \%$ of the human atrial cells they studied. This contrasts with the recently published observation that $\mathrm{I}_{\mathrm{Ca}(\mathrm{TX})}$ was recorded in all myocytes isolated from adult mouse interventricular septum [40], but with considerable variability in peak current densities among cells. We also found a great variability of peak FLVA-I $\mathrm{Ca}_{\mathrm{a}}$ density in PVCM, especially in the presence of $5 \mathrm{mM} \mathrm{Ca}^{2+}$, which could not be explained by the CM size approximated by its membrane capacitance. Moreover, it was not possible to visually distinguish CM with or without FLVA current. Different levels of expression of the channel within the CM population might possibly contribute to the observed variability of FLVA$\mathrm{I}_{\mathrm{Ca}}$ density.

Our study of LVA Ca ${ }^{2+}$ channels in a large number of PV and LA CM has revealed that an important T-type $\mathrm{Ca}^{2+}$ current was present in only $13.5 \%$ of PVCM (31 out of $228 \mathrm{CM}$ ) and barely visible in LACM. Although the only T-type $\mathrm{Ca}^{2+}$ channels mRNA found in rat atria are those of $\mathrm{Ca}_{\mathrm{v}} 3.1$ and $\mathrm{Ca}_{v} 3.2, \mathrm{Ca}_{v} 3.1$ being the predominant form $[22,24]$, it was not possible to determine from our results to which type of $\mathrm{Ca}_{\mathrm{v}} 3 . \mathrm{x}$ channel this large current might correspond in PV. Indeed, using three different test potentials, we determined in the presence of $5 \mathrm{mM} \mathrm{Ca}{ }^{2+} \mathrm{V}_{0.5}$ values of -65 to $-69 \mathrm{mV}$ which were not statistically different. Taking into account the $\mathrm{Ca}^{2+}$ screening effect, these values are similar to those reported for $\mathrm{Ca}_{v} 3.1$ and $\mathrm{Ca}_{\mathrm{v}} 3.2\left(\mathrm{~V}_{0.5}\right.$ of $\sim-70 \mathrm{mv}$ in the presence of $\left.2 \mathrm{mM} \mathrm{Ca}^{2+} ;[8]\right)$. The presence of this large T-type current only in PVCM contributes to define a large $\mathrm{Ca}^{2+}$ window current in these cells and thus to facilitate $\mathrm{Ca}^{2+}$ dependent arrhythmogenic activity. Our results from $\mathrm{Ca}^{2+}$ channel availability are also not in favour of the presence of $\mathrm{Ca}_{\mathrm{v}} 1.3$ channels which inactivate at less negative potentials than the T type channels [8].

Testing the potential role of FLVA-I $\mathrm{Ca}_{\mathrm{a}}$ as a trigger of CAA is not possible in the absence of specific blockers. In a previous study, we have shown that TTX was able to decrease CAA incidence, burst duration and to increase burst interval [27] and we concluded that all these effects could be attributed to $\mathrm{Na}^{+}$channels blockade. At present, we cannot exclude the participation of FLVA-I $\mathrm{I}_{\mathrm{Ca}}$ to CAA. Indeed, at the concentration of $10 \mu \mathrm{M}$ used to induce CAA [12, 27, 29], NE increased both FLVA$\mathrm{I}_{\mathrm{Ca}}(\sim 2.5$ times $)$ and $\mathrm{I}_{\mathrm{Camax}}(\sim+31 \%, \mathrm{n}=10)$ and this might also contribute to facilitate CAA. Although diltiazem did not block FLVA-I $I_{\text {a, }}$ it suppressed CAA in a concentration-dependent manner probably by a direct action on $\mathrm{I}_{\mathrm{CaL}}[6]$. Thus although FLVA-I $\mathrm{Ca}_{\mathrm{a}}$ could modulate CAA, it is probably not the main trigger as it is also present in LA (albeit smaller) in which CAA cannot be induced $[12,29]$. 
The PV myocardium is characterized by a marked structural heterogeneity in terms of tubular system, $\mathrm{Ca}_{v} 1.2$ channels localization and $\mathrm{Ca}_{v} 1.2$-ryanodine receptor coupling [34] with functional consequences on $\mathrm{Ca}^{2+}$ cycling. Our present study indicates that it might also be heterogeneous in terms of FLVA and $\mathrm{Ca}_{v} 3 . x$ channels distribution, which could therefore contribute to enhance $\mathrm{Ca}^{2+}$ influx near the resting potential and to induce arrhythmias in some parts of the PV. Moreover, the presence of a large $\mathrm{Ca}_{v} 3 . x$ current in a small number of PVCM might underlie localization of ectopic foci in the PV myocardial sleeve, as reported in humans $[4,17]$ and more recently in rat PV [35].

\section{ACKNOWLEDGMENTS}

The author is indebted to Dr lan Findlay for helpful discussions and critical comments on the manuscript.

\section{SOURCES OF FUNDING}

This work was financially supported by the University of Tours and the Centre National de la Recherche Scientifique.

\section{DISCLOSURES}

None 


\section{REFERENCES}

1. Aggarwal R, Shorofsky SR, Goldman L, Balke CW (1997). Tetrodotoxin-blockable calcium currents in rat ventricular myocytes; a third type of cardiac cell sodium current. J Physiol. 505:353-369. doi: 10.1111/j.1469-7793.1997.353bb.x. PMID: 9423179

2. Akaike N, Takahashi K (1992). Tetrodotoxin-sensitive calcium-conducting channels in the rat hippocampal CA1 region. J Physiol. 450:529-546. doi: 10.1113/jphysiol.1992.sp019141. PMID: 1338651

3. Alvarez J, Salinas-Stefanon E, Orta G, Ferrer T, Talavera K, Galan L, Vassort G (2004). Occurrence of a tetrodotoxin-sensitive calcium current in rat ventricular myocytes after longterm myocardial infarction. Cardiovasc Res. 63:653-661. doi: 10.1016/j.cardiores.2004.05.010. PMID: 15306221

4. Arentz T, Haegeli L, Sanders P, Weber R, Neumann FJ, Kalusche D, Haïssaguerre M (2007). High-density mapping of spontaneous pulmonary vein activity initiating atrial fibrillation in humans. J Cardiovasc Electrophysiol. 18:31-38. doi: 10.1111/j.1540-8167.2006.00682.x. PMID: 17229297

5. Bodi I, Nakayama H, Schwartz A. Tetrodotoxin-sensitive Ca ${ }^{2+}$ currents, but no T-type currents in normal, hypertrophied, and failing mouse cardiomyocytes (2016). J Cardiovasc Pharmacol 68:452-434. doi: 10.1097/FJC.0000000000000432. PMID: 27617699

6. Bredeloux P, Aguettaz E, Findlay I, Maupoil V (2012). Contribution of calcium to the catecholaminergic automatic activity of rat pulmonary veins. Arch Cardiovasc Dis Suppl. 2:42 (Abstract 0179).

7. Cain SM, Snutch TP (2010). Contributions of T-type calcium channels isoforms to neuronal firing. Channels 4:475-482. doi: 10.4161/chan.4.6.14106. PMID: 21139420

8. Chemin J, Monteil A, Perez-Reyes E, Bourinet E, Nargeot J, Lory P (2002). Specific contribution of human T-type calcium channel isotypes $\left(\alpha_{1 G}, \alpha_{1 H}\right.$ and $\left.\alpha_{11}\right)$ to neuronal excitability. J Physiol. 540:3-14. doi: 10.1113/jphysiol.2001.013269. PMID: 11927664

9. Chen-Izu Y,Sha Q, Shorofsky SR, Robinson SW, Wier WG, Goldman L, Balke CW (2001). I Ia(TTX) channels are distinct from those generating the classical $\mathrm{Na}^{+}$current. Biophys J. 81:26472659. doi: 10.1116/ S0006-3495(01)75908-5. PMID: 11606278

10. Cole WC, Chartier D, Martin M, Leblanc N (1997). $\mathrm{Ca}^{2+}$ permeation through $\mathrm{Na}^{+}$channels in 0.guinea pig ventricular myocytes. Am J Physiol. 273:H128-H137. doi: 10.1152/ajpheart.1997.273.1.H128. PMID: 9249483

11. de Almeida OP, Böhm GM, Carvalho MP, de Carvalho AP (1975). The cardiac muscle in the pulmonary vein of the rat: a morphological and electrophysiological study. J Morph. 145:409434. DOI: 10.1002/jmor.1051450403. PMID: 1127702

12. Doisne N, Maupoil V, Cosnay P, Findlay I (2009). Catecholaminergic automatic activity in the rat pulmonary vein: electrophysiological differences between cardiac muscle in the left atrium and pulmonary vein. Am J Physiol Heart Circ Physiol. 297:H102-H108.

doi: 10.1152/ajpheart.00256.2009. PMID: 19429824 
13. Ehrlich JR, Cha TJ, Zhang L, Chartier D, Melnyk P, Hohnloser SH, Nattel S (2003). Cellular electrophysiology of canine pulmonary vein cardiomyocytes: action potential and ionic current properties. J Physiol. 551:801-813. doi: 10.1113/jphysiol.2003.046417. PMID: 12847206

14. Favre I, Moczydlowski E, Schild L (1996). On the structural basis for ionis selectivity among $\mathrm{Na}^{+}, \mathrm{K}^{+}$, and $\mathrm{Ca}^{2+}$ in the voltage-gated sodium channel. Biophys J; 71:3110-3125.

doi: 10.1016/S0006-3495(96)79505-X. PMID: 23746512

15. Fedida D, Noble D, Spindler AJ (1988). Mechanism of the use-dependence of Ca2+ current in guinea-pig myocytes. J Physiol. 405:461-475. doi: 10.1113/jphysiol.1988.sp017342. PMID: 2855643

16. Guatimosim S, Sobie EA, Dos Santo Cruz J, Martin LA, Lederer WJ (2001). Molecular identification of a TTX-sensitive $\mathrm{Ca}^{2+}$ current. Am J Physiol Cell Physiol. 280:C1327-C1339. doi: 10.1152/ajpcell.2001.280.5.C1327. PMID: 11287346

17. Haïssaguerre $M$, Jaïs $P$, Shah DC, Takahashi A, Hocini M, Quiniou G, Garrigue $S$, Le Mouroux A, Le Métayer P, Clémenty J (1998). Spontaneous initiation of atrial fibrillation by ectopic beats originating in the pulmonary veins. N Engl J Med 339:659-666.

doi: 10.1056/NEJM199809033391003. PMID: 9725923

18. Heubach JF, Köhler A, Wettwer E, Ravens U (2000). T-type and tetrodotoxin-sensitive $\mathrm{Ca}^{2+}$ currents coexist in guinea pig ventricular myocytes and are both blocked by mibefradil. Circ Res. 86:628-635. doi: 10.1161/01.RES.86.6.628. PMID: 10746997

19. Hille B (2001). Ion channels of excitable membranes (3rd edition). Sunderland MA: Sinauer Associates, Inc.

20. Hosoyamada Y, Ichimura K, Koizumi K, Sakai T (2010). Structural organization of pulmonary veins in the rat lung, with sppecail emphasis on the musculature consisting of cardiac and smooth muscles. Anat Sci Int. 85:152-159. doi: 10.1007/s12565-009-0071-9. PMID:

20082232.

21. Klavins JV (1963). Demonstration of striated muscle in the pulmonary veins of the rat. J Anat, Lond. 97:239-241. PMID: 14033309

22. Lee JH, Daud AN, Cribbs LL, Lacerda AE, Pereverzev A, Klöckner U, Schneider T, Perez-Reyes E (1999). Cloning and expresssion of a novel member of the low voltage-activated T-type calcium channel family. J Neurosci. 19:1912-1921. doi: 10.1523/JNEUROSCI.19-06-01912. PMID: 10066244

23. Lemaire S, Piot C, Seguin J, Nargeot J, Richard S (1995). Tetrodotoxin-sensitive $\mathrm{Ca}^{2+}$ and $\mathrm{Ba}^{2+}$ currents in human atrial cells. Receptors and Channels 3:71-81. PMID: 8581402

24. Leuranguer V, Monteil A, Bourinet E, Dayanithi G, Nargeot J (2000). T-type calcium currents in rat cardiomyocytes during postnatal development: contribution to hormone secretion. Am J Physiol Heart Circ Physiol. 279:H2540-H2548. doi: 10.1152/ajpheart.2000.279.5.H2540. PMID: 11045992 
25. Lewis CA (1979). Ion-concentration dependence of the reversal potential and the single channel conductance of ion channels at the frog neuromuscular junction. J Physiol. 286:417445. doi: 10.1113/jphysiol.1979.sp012629. PMID: 312319

26. Mahida S, Sacher F, Derval N, Berte B, Yamashita S, Hooks D, Denis A, Amraoui S, Hocini M, Haissaguerre $M$, Jais $P$ (2015). Science linking pulmonary veins and atrial fibrillation. Arrhythm Electrophysiol Rev. 4:40-43. doi: 10.15420/aer.2015.4.1.40. PMID: 26835098

27. Malécot CO, Bredeloux P, Findlay I, Maupoil V (2015). A TTX-sensitive resting $\mathrm{Na}^{+}$ permeability contributes to the catecholaminergic automatic activity in rat pulmonary vein. $J$ Cardiovasc Electrophysiol. 26:311-319. doi: 10.1111/jce.12572. PMID: 25346483

28. Mangoni ME, Couette B, Bourinet E, Platzer J, Reimer D, Striessnig J, Nargeot J (2003) Functional role of L-type Cav1.3 $\mathrm{Ca}^{2+}$ channels in cardiac pacemaker activity. Proc Natl Acad Sci USA. 100:5543-5548. doi: 10.1073/pnas.0935295100. PMID: 12700358

29. Maupoil V, Bronquard C, Freslon JL, Cosnay P, Findlay I (2007). Ectopic activity in the rat pulmonary vein can arise from simultaneous activation of alpha1- and beta1-adrenoceptors. Br J Pharmacol. 150:899-905. doi: 10.1038/sj.bjp.0707177. PMID: 17325650

30. Melnyk P, Ehrlich JR, Pourrier M, Villeneuve L, Cha TJ, Nattel S (2005). Comparison of ion channel distribution and expression in cardiomyocytes of canine pulmonary veins versus left atrium. Cardiovasc Res. 65:104-116. doi: 10.1016/j.cardiores.2004.08.014 PMID: 15621038

31. Mesirca P, Torrente AG, Mangoni ME (2015). Functional role of voltage gated $\mathrm{Ca}^{2+}$ channels in heart automaticity. Front Physiol. 6:19. doi: 10.3389/fphys.2015.00019. PMID: 25698974

32. Mueller-Koecker J, Beitinger F, Fernandez B, Bahlmann O, Assmann G, Troidl C, Dimomeletis I, Kääb S, Deindl E (2008). Of rodents and humans: a light microscopic and ultrastructural study on cardiomyocytes in pulmonary veins. Int J Med Sci. 5:152-158.

doi: 10.7150/ijms.5.152. PMID: 18612369.

33. Nilius B, Talavera K, Owsianik G, Prenen J, Droogmans G, Voets T (2005). Gating of TRP channels: a voltage connection? J Physiol. 567.1:35-44. doi: 10.1113/jphysiol.2005.088377. PMID: 15878939.

34. Pasqualin C, Yu A, Malécot CO, Gannier F, Cognard C, Godin-Ribuot D, Morand J, Bredeloux P, Maupoil V (2018). Structural heterogeneity of the rat pulmonary vein myocardium: consequences on intracellular calcium dynamics and arrhythmogenic potential. Sci Rep. 8:3244. doi: 10.1038/s41598-018-21671-9. PMID: 29459735

35. PasqualinC, Guilloteau C, GannierF, Peineau N, Bredeloux P, Maupoil V (2019). Mapping of the catecholaminergic automatic activity from its foci within the pulmonary veins to the left atria in rat. Arch Cardiovasc Dis Suppl. 11:267. (Abstract 529). doi: 10.1016/j.acvdsp.2019.02.181

36. Pidoplichko VI (1986). Two different tetrodotoxin-separable inward sodium currents in the membrane of isolated cardiomyocytes. Gen Physiol Biophys.6:593-604. PMID: 2435613 
37. Sha Q, Robinson SW, McCulle SL, Shorofsky SR, Welling PA, Goldman L, Balke CW (2003). An antisense oligonucleotide against $\mathrm{H} 1$ inhibits the classical sodium current but not $I_{\mathrm{Ca}(\mathrm{TT})}$ in rat ventricular cells. J Physiol. 547:435-440. doi: 10.1113/jphysiol.2002.035246. PMID: 12562298

38. Sun Y-M, Favre I, Schild L, Moczydlowski E (1997). On the structural basis for size-selective permeation of organic cations through the voltage-gated sodium channel. Effects of Alanine mutations at the DEKA locus on selectivity, inhibition by $\mathrm{Ca}^{2+}$ and $\mathrm{H}^{+}$, and molecular sieving. J Gen Physiol. 110:693-715. doi: 10.1085/jgp.110.6.693. PMID: 9382897

39. Takahashi K, Kameda H, Kataoka M, Ueno S, Akaike N (1992). Effects of $\mathrm{Ca}^{2+}$ antagonists and antiepileptics on tetrodotoxin-sensitive $\mathrm{Ca}^{2+}$-conducting channels in isolated rat hippocampal CA1 neurons. Neurosci Lett. 148:60.62. doi: 10.1016/0304-3940(92)90804G. PMID: 1338651

40. Wang W, Mellor RL, Nerbonne JM, Balke CW (2019). Regional differences in the expression of tetrodotoxin-sensitive inward $\mathrm{Ca}^{2+}$ and outward $\mathrm{Cs}^{+} / \mathrm{K}^{+}$currents in mouse and human ventricles. Channels 13:72-87. doi: 10.1080/19336950.2019.1568146. PMID: 30704344

41. Zhou W, Goldin AL (2004). Use-dependent potentiation of the $\mathrm{Na}_{\mathrm{v}} 1.6$ sodium channel. Biophys J. 87:3862-3872. doi: 10.1569/biophysj.104.045963. PMID: 15465873 


\section{FIGURE LEGENDS}

Figure 1. Low voltage activated (LVA) $\mathrm{Ca}^{2+}$ currents in PVCM in the presence of $5 \mathrm{mM} \mathrm{Ca}^{2+}$.

a1, fast activating and inactivating (FLVA) current; a2, slow activating and inactivating current (SLVA); a3, fast activating and slow inactivating current (FSLVA). The test pulses were applied from the prepulse voltage of $-100 \mathrm{mV}$ to $-35 \mathrm{mV}(\mathrm{a} 1$ and $\mathrm{a} 3$ ) and $-40 \mathrm{mV}(\mathrm{a} 2)$. The symbols above each trace refer to the mean current voltage (IV) relationships shown in $\mathbf{b}$. Data points are mean \pm SE of $n$ PVCM. (O), $\mathrm{n}=12 ;(\boldsymbol{\Delta}), \mathrm{n}=37 ;(\mathbf{O}), \mathrm{n}=10$.

Figure 2. TTX-sensitive, ranolazine insensitive FLVA current in PVCM.

a, representative recordings of the effects of $10 \mu \mathrm{M}$ TTX on the FLVA current recorded in the presence of $5 \mathrm{mM} \mathrm{Ca}^{2+}$. a1, complete block and a2, unveiling of a slower activating and inactivating $\mathrm{Ca}^{2+}$ current component. Test pulses applied from the pre-pulse of $-100 \mathrm{mV}$ to $-30 \mathrm{mV}(\mathrm{a} 1)$ and -35 $\mathrm{mV}$ (a2). a3, mean current voltage (IV) relationships of the global calcium current in control conditions and in the presence of $10 \mu \mathrm{M} \mathrm{TTX}, \mathrm{n}=8$. b, lack of effect of $10 \mu \mathrm{M}$ ranolazine (Rano; b1, test pulse from $-100 \mathrm{mV}$ to $-35 \mathrm{mV}$ ) in the presence of $5 \mathrm{mM} \mathrm{Ca}^{2+} . \mathbf{b 2}$, mean IV curves in control conditions and in the presence of $10 \mu \mathrm{M}$ Rano $(n=6)$.

Figure 3. Divalent ion permeation through LVA channels in PVCM.

$\mathbf{a}$, external $\mathrm{Ca}^{2+}$-dependence of the FLVA current. $\mathbf{b}$ and $\mathbf{c}$, representative traces of the effects of $\mathrm{Sr}^{2+}$ (b) or $\mathrm{Ba}^{2+}$ (c) equimolar substitution for $\mathrm{Ca}^{2+}$ on the current. In $\mathbf{c 2}, \mathrm{Ba}^{2+}$ substitution for $\mathrm{Ca}^{2+}$ reveals a slower activating and inactivating current component. Test pulses applied from the pre-pulse of -100 $m V$ to $-40 m V(a)$ or $-35 m V(b$ and $c)$.

\section{Figure 4. Permeability to monovalent cations of the FLVA channel in PVCM.}

Representative traces of $\mathrm{Na}^{+}(\mathbf{a} 1)$ and $\mathrm{K}^{+}$(b1) permeation in the presence of $5 \mathrm{mM} \mathrm{Ca}^{2}$. Test pulses applied from the pre-pulse of $-100 \mathrm{mV}$ to $-40 \mathrm{mV}$ (a1) and $-35 \mathrm{mV}$ (b1). a2 and b2, mean IV curves. $\mathrm{Na}^{+}: \mathrm{n}=6 . \mathrm{K}^{+}: \mathrm{n}=8$. $\mathrm{c}$, time course of a representative experiment illustrating permeation of $\mathrm{K}^{+}$ions through FLVA channel in the presence or absence of $5 \mathrm{mM} \mathrm{Ca}^{2+}\left(\mathrm{Ca}^{2+}\right.$ replaced by equimolar $\left.\mathrm{Mg}^{2+}\right)$. Test pulses applied from the pre-pulse of $-100 \mathrm{mV}$ to $-35 \mathrm{mV}$ at $0.2 \mathrm{~Hz}$.

\section{Figure 5. Conductance of the FLVA channel.}

$\mathbf{a}$ and $\mathbf{b}$, voltage-dependence of the FLVA channel conductance in $5 \mathrm{mM} \mathrm{Ca}^{2+}$ control conditions and in the additional presence of either $\mathrm{Na}^{+}(a, n=6)$ or $\mathrm{K}^{+}(b, n=8)$. Smooth lines represent adjustments of Boltzmann functions to the mean data points, as described in the text. c, channel conductance to $\mathrm{Na}^{+}$ 
or $\mathrm{K}^{+}$in the presence of $5 \mathrm{mM} \mathrm{Ca}{ }^{2+}$. Smooth line represents adjustment of the Langmuir isotherm equation to the mean data points (same $\mathrm{n}$ values as above). See text for details.

Figure 6. Sensitivity of the FLVA current in PVCM to L- and T-type $\mathrm{Ca}^{2+}$ channel blockers.

$\mathbf{a}$ and $\mathbf{b}$, dihydropyridines sensitivity. $\mathbf{a} \mathbf{1}$ and b1, representative traces of the effects of $5 \mu \mathrm{M}$ Nifedipine (Nif) and $0.3 \mu \mathrm{M}$ BayK8644 (BayK) on the currents recorded from the pre-pulse of $-100 \mathrm{mV}$ to $-35 \mathrm{mV}$ and $-40 \mathrm{mV}$, respectively. a2 and b2, mean IV curves in control conditions with $5 \mathrm{mM} \mathrm{Ca}{ }^{2+}$ $+5 \mathrm{mM} \mathrm{K}^{+}$and then in the additional presence of $5 \mu \mathrm{M} \mathrm{Nif}(\mathrm{n}=5)$ or $0.3 \mu \mathrm{M}$ BayK $(n=6)$, respectively. $\left({ }^{*}\right): P<0.05$ vs. control. $\mathbf{c}$ and $\mathbf{d}$, representative traces of the effects of $0.1 \mu \mathrm{M}$ TTA-A2 and $40 \mu \mathrm{M}$ $\mathrm{NiCl}_{2}$, respectively, on the FLVA current recorded in the presence of $2 \mathrm{mM} \mathrm{Ca}^{2+}$. Test pulses applied from the pre-pulse of $-100 \mathrm{mV}$ to $-45 \mathrm{mV}$. In $\mathrm{C}, \mathrm{C}$ and $\mathrm{T}$ represent control and TTA-A2 traces, respectively.

Figure 7. $-40 \mathrm{mV}$ pre-pulse-sensitive $\mathrm{Ca}^{2+}$ currents.

Mean IV curves of the currents sensitive to $200 \mathrm{~ms}$ pre-pulses to $-40 \mathrm{mV}$ recorded in the presence of $2 \mathrm{mM} \mathrm{Ca}^{2+}$ in the three groups of PVCM (a) and LACM (b). Each of these groups had been visually distinguished on the basis of the shape of their IV curve recorded from the normal pre-pulse to -100 mV (Fig. 1b). SLVA current (O) PVCM, $n=4$ and LACM, $n=5$. FLVA current ( $\mathbf{\Delta}$ ) PVCM, $n=7$ and LACM, $\mathrm{n}=4$. FSLVA current (O) PVCM, $\mathrm{n}=5$ and LACM, $\mathrm{n}=10$. 
Table 1: Fast LVA current characteristics in PV and LA CM

\begin{tabular}{|c|c|c|c|c|c|}
\hline & \multicolumn{3}{|c|}{ PVCM } & \multicolumn{2}{|l|}{ LACM } \\
\hline & $2 \mathrm{mM}\left[\mathrm{Ca}^{2+}\right]_{0}(\mathrm{n})$ & $5 \mathrm{mM}\left[\mathrm{Ca}^{2+}\right]_{0}(\mathrm{n})$ & $\begin{array}{c}P \\
\text { (2 vs } 5 \mathrm{mM})\end{array}$ & $2 \mathrm{mM}\left[\mathrm{Ca}^{2+}\right]_{0}(\mathrm{n})$ & $\begin{array}{c}P \\
\text { (LA vs } P V \text { CM) }\end{array}$ \\
\hline Threshold (mV) & $-53.85 \pm 0.61(63)$ & $-53.22 \pm 0.95(45)$ & 0.337 & $-54.64 \pm 0.55(50)$ & 0.437 \\
\hline Peak voltage (mV) & $-43.33 \pm 0.54(63)$ & $-37.55 \pm 0.96(45)$ & $<0.001$ & $-41.10 \pm 2.55(50)$ & 0.251 \\
\hline $\begin{array}{l}\text { Peak amplitude } \\
\qquad(\mathrm{pA} / \mathrm{pF})\end{array}$ & $-0.584 \pm 0.067(63)$ & $-1.556 \pm 0.201(45)$ & $<0.001$ & $-0.353 \pm 0.035(50)$ & 0.012 \\
\hline (\% of $\left.I_{\text {Camax }}\right)$ & $13.45 \pm 1.61(63)$ & $26.1 \pm 3.6(45)$ & $<0.001$ & $9.95 \pm 1.07(50)$ & 0.189 \\
\hline Apparent $\mathrm{V}_{\text {rev }}(\mathrm{mV})$ & $-31.58 \pm 0.56(58)^{*}$ & $-20.22 \pm 1.03(45)$ & $<0.001$ & $-32.10 \pm 0.64(50)$ & 0.542 \\
\hline
\end{tabular}

PVCM: pulmonary vein cardiomyocytes; $L A C M$, left atrial cardiomyocytes. $V_{\text {rev }}$ : current reversal potential. $\mathrm{P}$ values for Mann-Whitney Rank Sum test. $\left({ }^{*}\right)$ Apparent $\mathrm{V}_{\text {rev }}$ was too small in 5 PV CM to be accurately determined 

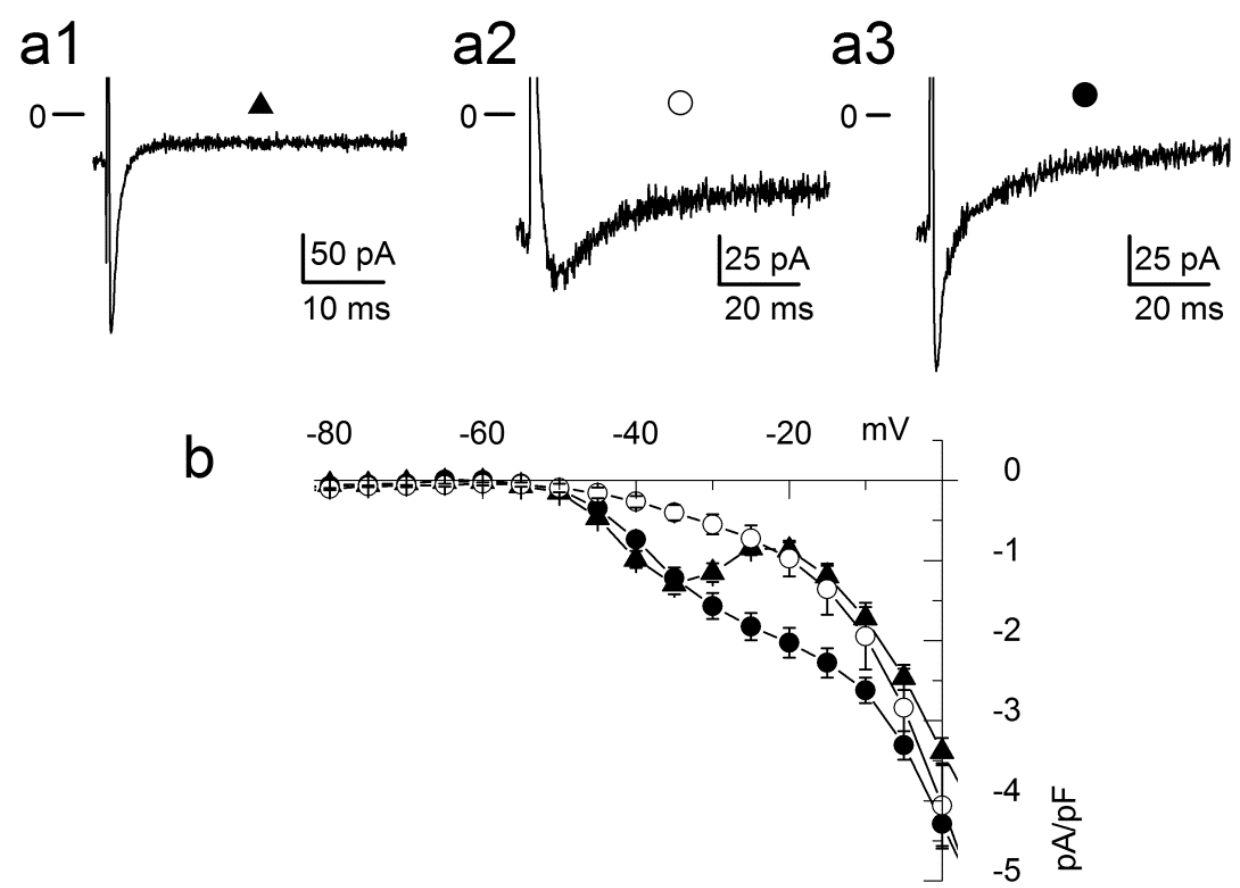

Figure 1

graphics program : OriginPro 7 


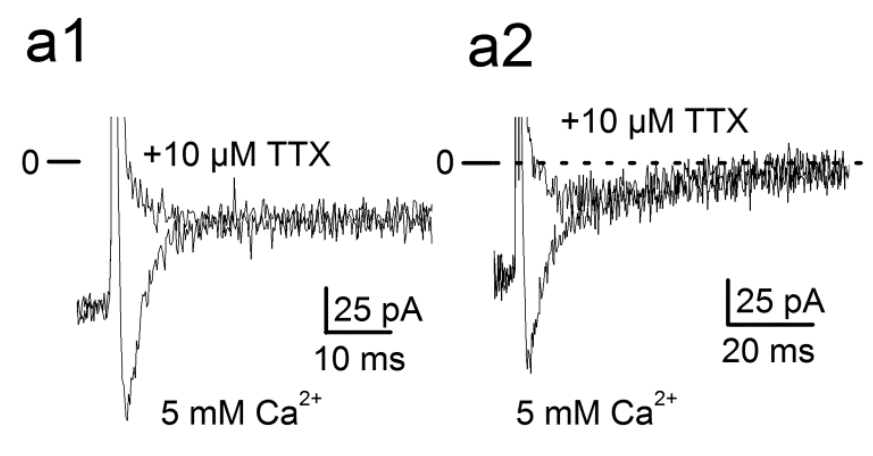

b1

a3
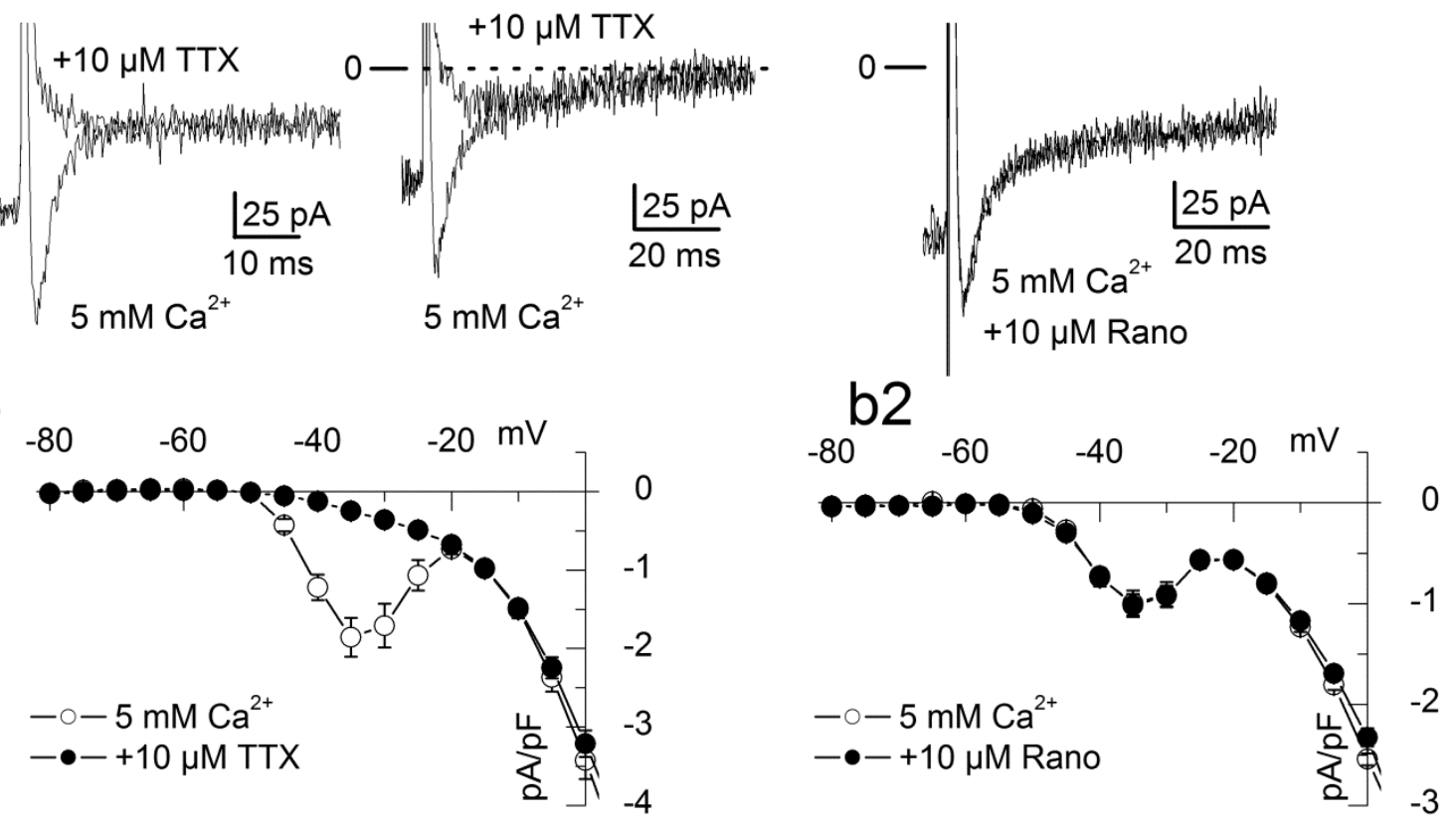

Figure 2

graphics program: OriginPro 7 

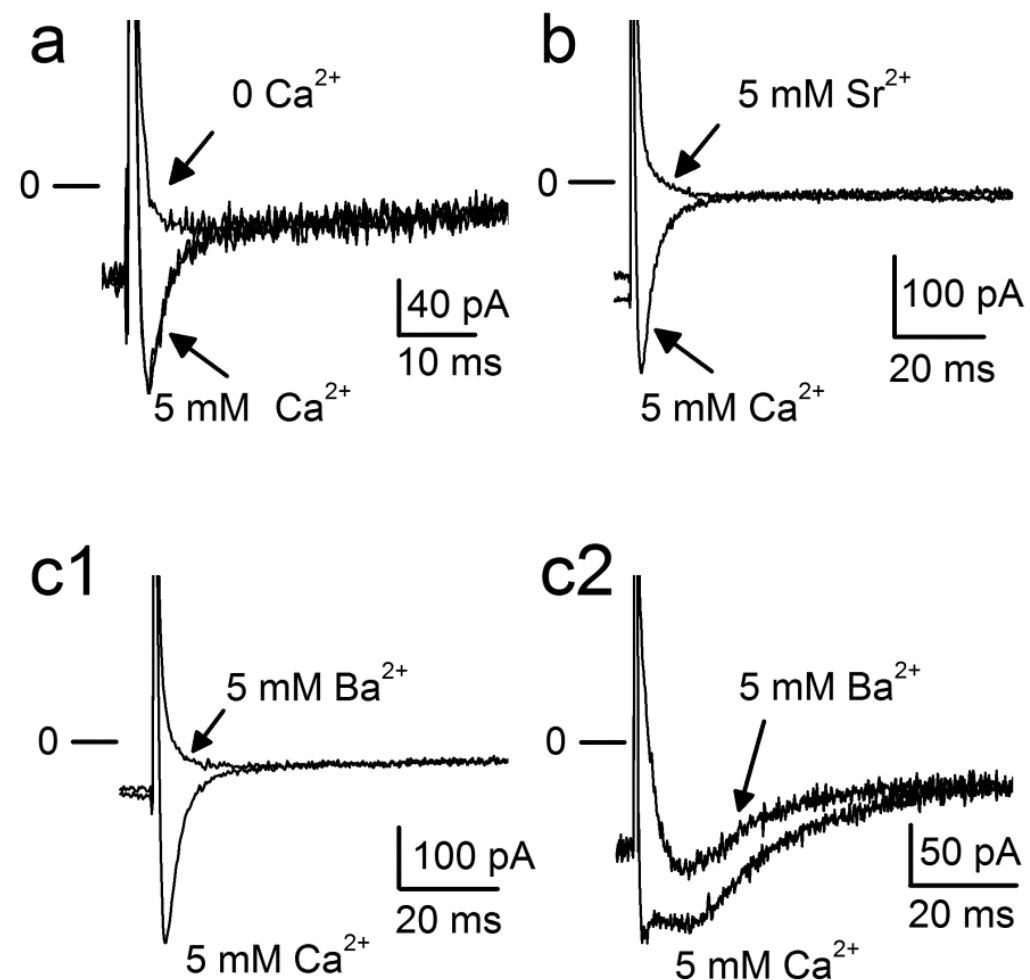

Figure 3

graphics program: OriginPro 7 
a1

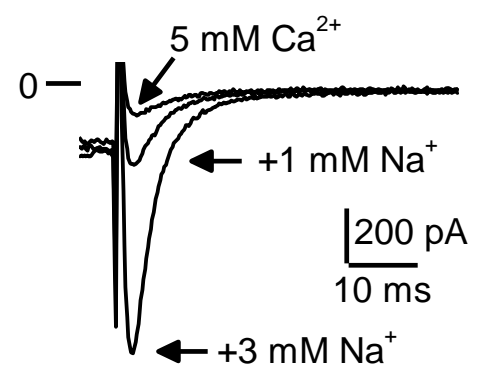

b1

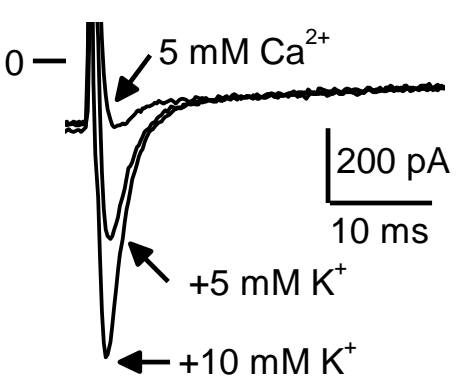

a2

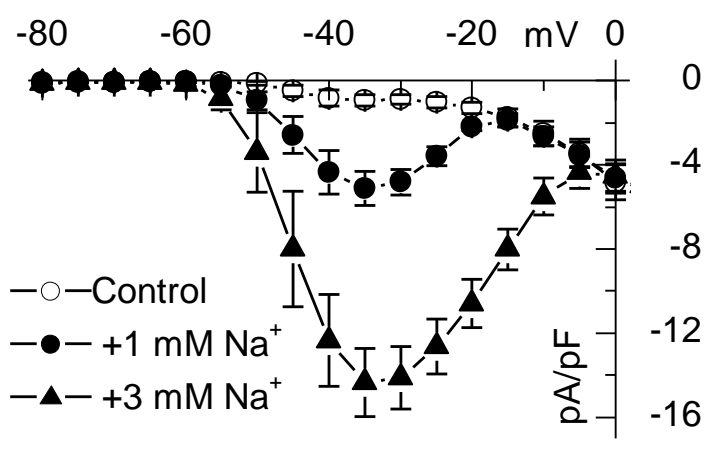

b2

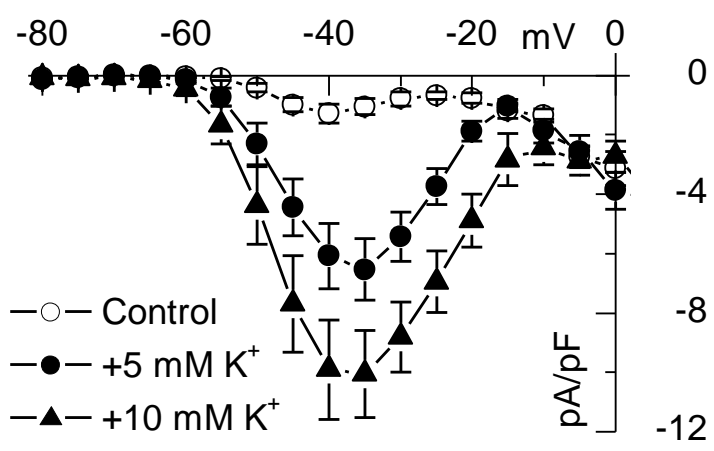

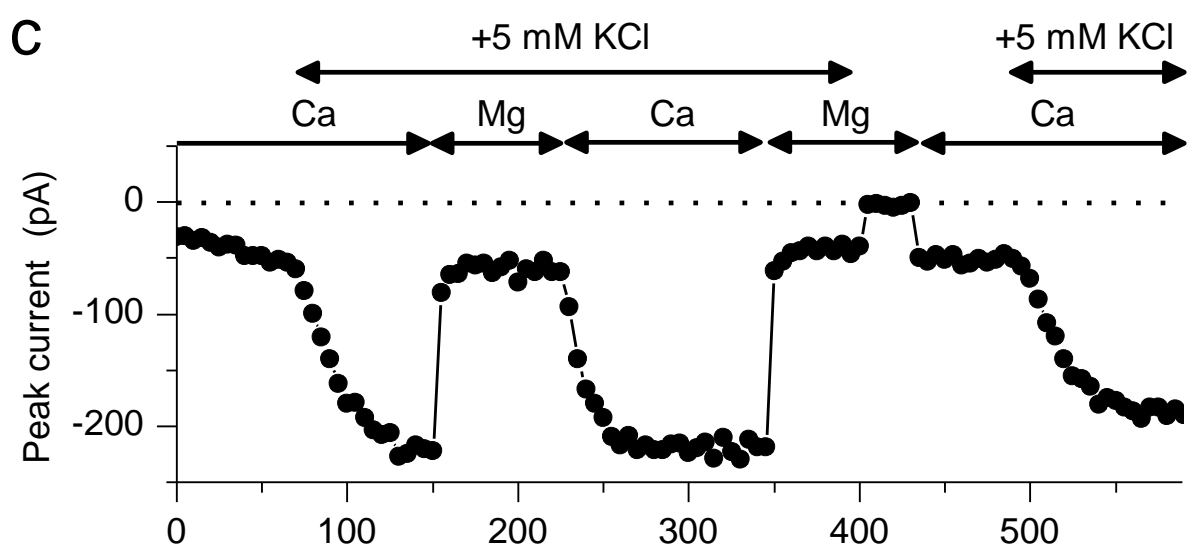

Time (s)

Figure 4

graphics program: OriginPro 7 

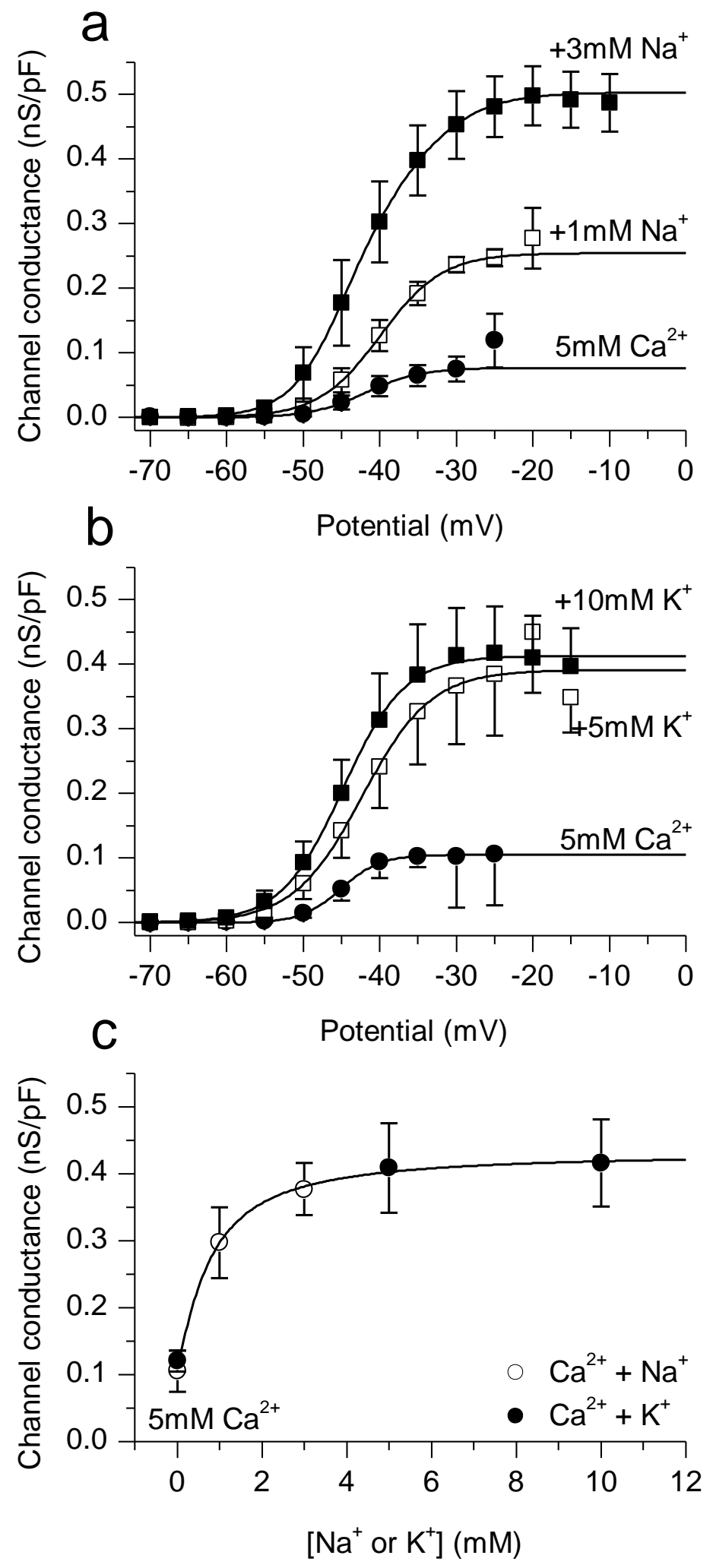

Figure 5 -

graphics program OriginPro 7 
a1

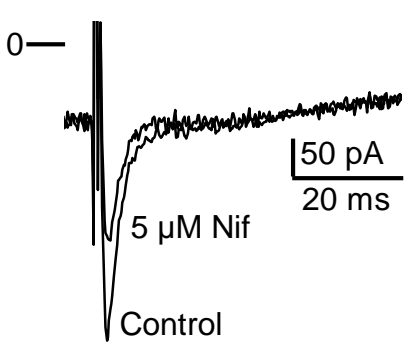

b1

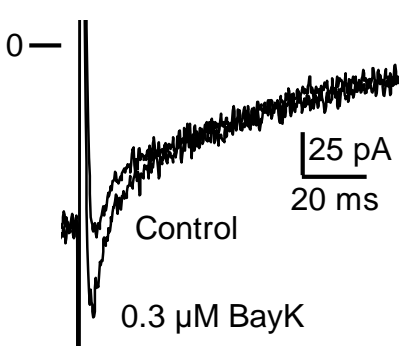

C

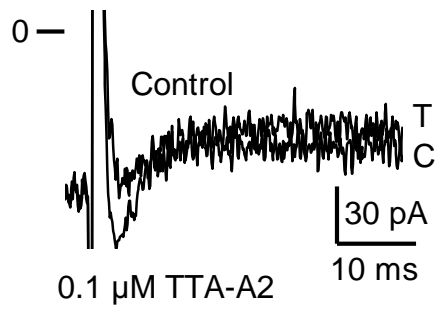

a2

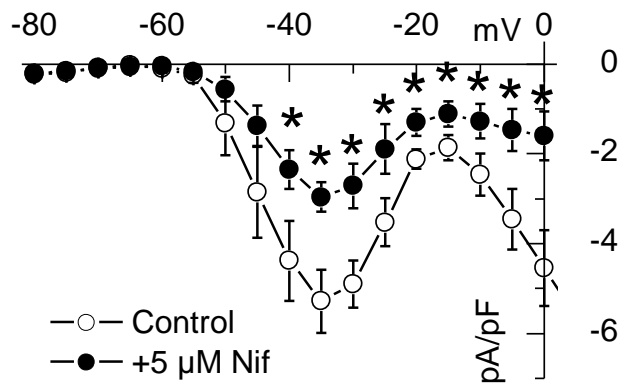

b2

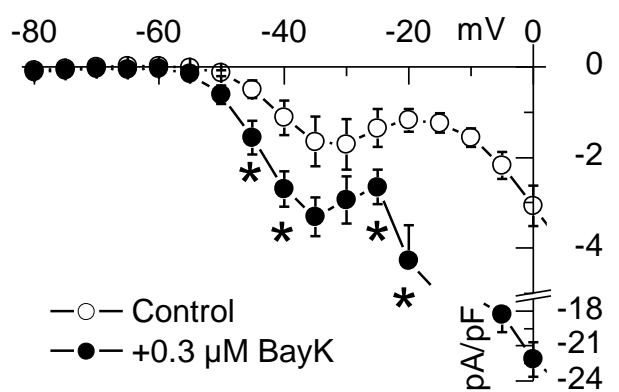

d

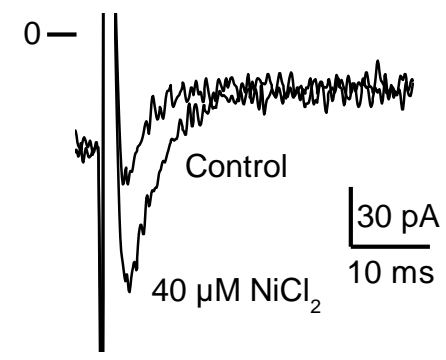

Figure 6

graphics program: OriginPro 7 
a

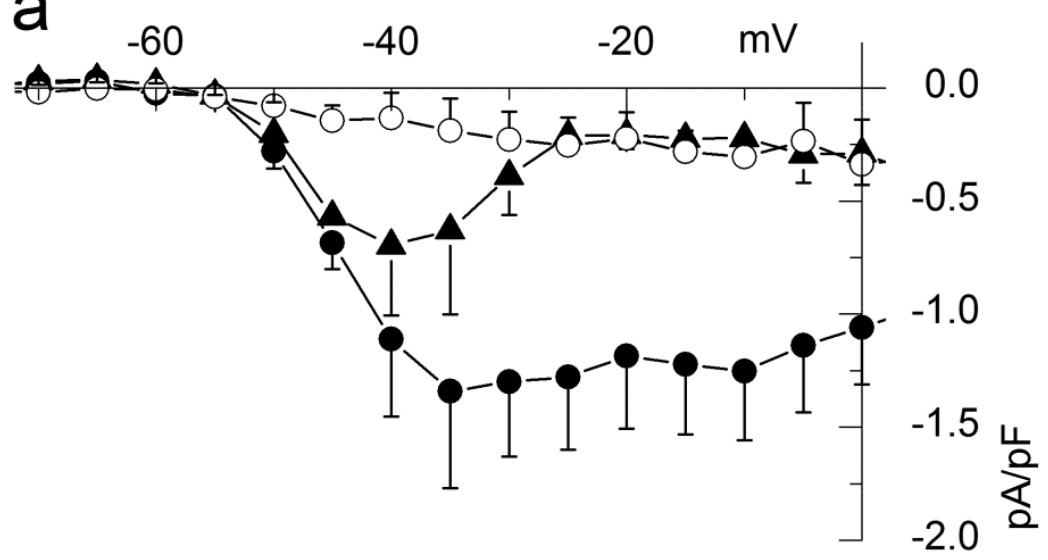

b

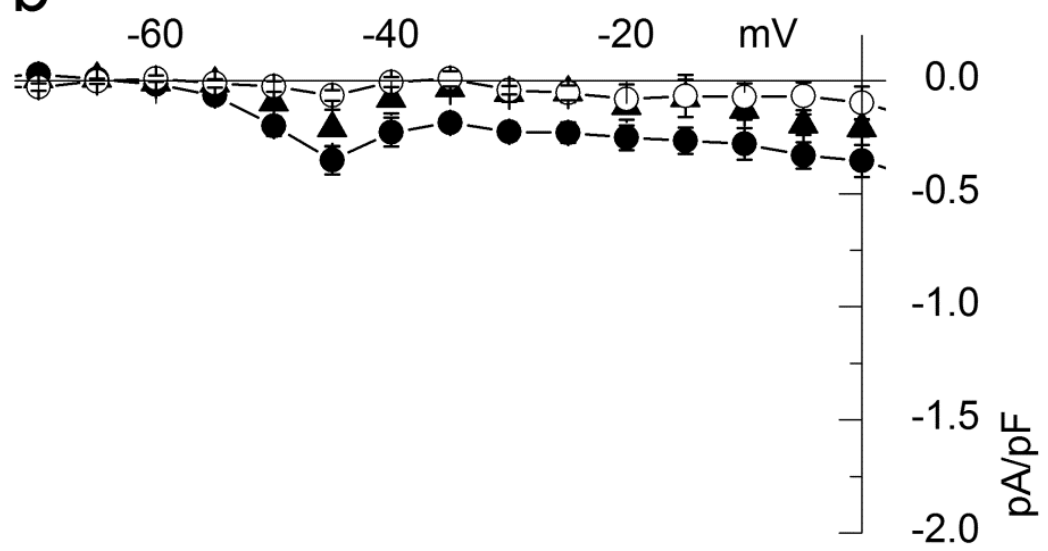

Figure 7

graphics program: OriginPro 7 


\title{
Supplementary Material
}

\section{Low voltage-activated channels in rat pulmonary vein cardiomyocytes: Coexistence of a non-selective cationic channel and of T-type Ca channels}

\author{
Claire O. Malécot ${ }^{(1)}$
}

(1) Centre National de la Recherche Scientifique

Université de Tours, Université de Poitiers, Laboratoire Signalisation et Transports Ioniques Membranaires, EA

7349, 37200 Tours, France

e-mail: malecot@univ-tours.fr

\section{Methods}

Male Wistar rats (350-480g; CER Janvier, Le Genest St Isle, France) were anesthetized by intraperitoneal injection of pentobarbital $(60 \mathrm{mg} / \mathrm{kg}$ ). After intravenous injection of heparin (500 $\mathrm{IU} / \mathrm{kg}$ ), the heart and lung block was rapidly removed and placed in a dissecting dish that contained cold $\left(4^{\circ} \mathrm{C}\right.$ ) cardioplegic solution (in $\mathrm{mM}: 110 \mathrm{NaCl}, 1.2 \mathrm{CaCl}_{2}, 16 \mathrm{KCl}, 16 \mathrm{MgCl}_{2}, 10 \mathrm{NaHCO}_{3}$, and 10 glucose). Left and right superior PVs were dissected out under a stereomicroscope, just below the first bifurcation to exclude the junctional area with the left atrial wall. All protocols have been approved by the local ethical committee (Comité d'Ethique en Expérimentation Animale Val de Loire $\mathrm{n}^{\circ}$ 019, Tours, France; approval reference number APAFIS\#6649-2016090711251954 v2) and conform to the guidelines from Directive 2010/63/EU of the European Parliament.

\section{Cardiomyocytes Isolation}

Cardiac myocytes were enzymatically (liberase plus protease) isolated as previously described $[2,3]$ at $37^{\circ} \mathrm{C}$ from the left and right superior pulmonary veins (PV) and from the left atrial appendage $(\mathrm{LA})$. Liberase ${ }^{\mathrm{TM}}$ research grade $(0.6 \mathrm{U} / \mathrm{mL}$ ) and protease (Type XXIV, $1 \mathrm{U} / \mathrm{mL}$ ) were dissolved in a modified Krebs-Ringer-Bicarbonate (KRB) solution ( $\mathrm{pH} 7.4$ equilibrated with $95 \% \mathrm{O}_{2}-5 \%$ $\mathrm{CO}_{2}$ ) and containing (in $\mathrm{mM}$ ): $35 \mathrm{NaCl}, 4.75 \mathrm{KCl}, 1.19 \mathrm{KH}_{2} \mathrm{PO}_{4}, 16 \mathrm{Na}_{2} \mathrm{HPO}_{4}, 25 \mathrm{NaHCO}_{3}, 134$ sucrose, 10 HEPES buffer, 10 glucose. PV and LA were separately incubated at $37^{\circ} \mathrm{C}$ in the enzymatic solution until cells detachment. Enzymatic digestion was stopped by addition of foetal calf serum (20\%), bovine serum albumin (2\%) and protease inhibitor cocktail (set I, Calbiochem, UK, at the final recommended dilution). Supernatant was removed and replaced with calcium free Tyrode solution. Calcium concentration was then progressively increased to a final concentration of $1.36 \mathrm{mM}$. The normal Tyrode solution contained (in mM: $140 \mathrm{NaCl}, 5.4 \mathrm{KCl}, 1 \mathrm{MgCl}_{2}, 1.36 \mathrm{CaCl}_{2}, 0.33 \mathrm{NaH}_{2} \mathrm{PO}_{4}, 10$ HEPES buffer and 11 glucose, $\mathrm{pH}$ adjusted to 7.4 with $\mathrm{NaOH}$ ).

\section{Patch-clamp recording of the calcium current $I_{C a}$}

Patch pipettes ( 2.5 to $3.5 \mathrm{M} \Omega$ ) were pulled from thick wall borosilicate glass capillaries (Clark Electromedical Instruments, Harvard Apparatus, UK). An Axopatch 200A amplifier (Axon Instruments Inc., USA) connected to a PC computer running Clampex (pClamp9 software, Axon Instruments) 
through a Digidata 1200A interface (Axon Instruments) was used to control voltage and record currents. Cells were continuously held at $-70 \mathrm{mV}$ (holding potential, HP) and activating pulses were preceded by a 200 ms hyperpolarising pulse to $-100 \mathrm{mV}$. The data, acquired at $5 \mathrm{kHz}$ and filtered with an 8-pole lowpass Bessel filter at $2 \mathrm{kHz}$, were analysed offline with Clampfit.

The pipette and cell capacitances were compensated by $80 \%$. In order to have an adequate control of the membrane voltage and to improve the clamp speed, care was taken to select relatively

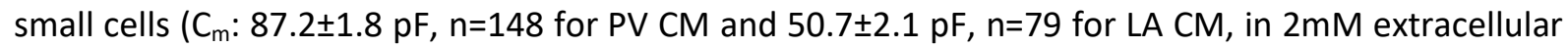
$\left(\mathrm{Ca}^{2+}\right)$.

\section{Chemicals and Reagents}

Chemicals were of reagent grade and obtained from Sigma-Aldrich (Saint Quentin Fallavier, France). Ranolazine (Tocris, R\&D Systems, Lille, France), tetrodotoxin (TTX; Alomone Labs Ltd, Jerusalem, Israel), (+)-cis-diltiazem and norepinephrine (NE; both from Sigma-Aldrich) were prepared as stock solutions in distilled water and kept frozen $\left(-20^{\circ} \mathrm{C}\right)$ until just prior to dilution in saline solutions. Nifedipine, ( \pm ) BayK 8644 , and TTA-A2 (Alomone Labs Ltd) were prepared as $10^{-2} \mathrm{M}$ stock solutions in DMSO. An equivalent concentration of DMSO was added to control solutions (the maximal final DMSO concentration of $0.05 \%$ reached in the presence of $5 \mu \mathrm{M}$ nifedipine had no effect per se). Liberase ${ }^{\mathrm{TM}}$ Research Grade and Protease XXIV were purchased from Sigma-Aldrich.

\section{Current apparent reversal potential and channel conductance determinations}

The apparent reversal potentials $\mathrm{V}_{\text {rev }}$ of LVA currents were determined by linear extrapolation of the descending limb of the current-voltage relationship to zero current.

The theoretical variation $\Delta \mathrm{V}_{\text {rev }}$ of the reversal potential of the current carried solely by ion $\mathrm{X}^{+}$ (see Table S1) when $\mathrm{X}^{+}$extracellular concentration was increased from concentration 1 to concentration 2 was calculated with the equation:

$$
\Delta V_{r e v}=\frac{R T}{F} \log _{e} \frac{\left[X^{+}\right]_{2}}{\left[X^{+}\right]_{1}}
$$

with the assumption that the intracellular $\mathrm{X}^{+}$concentration (due to $\mathrm{X}^{+}$influx) remained identical in both conditions.

Channel conductance was classically calculated from the peak current amplitude at each potential $\mathrm{V}$ and corresponding driving force with the equation:

$$
g_{i o n}=\frac{I_{i o n}}{\left(V-V_{\text {rev }}\right)}
$$

Conductance-voltage relationships were described by adjusting a single or double Boltzmann equation to the data points, as needed:

$$
g_{\text {ion }}=\frac{A_{1}}{\left(1+\exp \left(\frac{V-V_{0.5,1}}{k_{1}}\right)\right)}+\frac{A_{2}}{\left(1+\exp \left(\frac{V-V_{0.5,2}}{k_{2}}\right)\right)}
$$

with $A_{i}$ the amplitude, $V_{0.5, i}$ the mid activation voltage and $k_{i}$, the slope factor of component $i$ ( 1 or 2 ). 


\section{Relative permeability ratios, ion activities and liquid junction potential calculations}

Relative permeability ratios for $\mathrm{Ca}^{2+}$ over $\mathrm{Na}^{+}\left(\mathrm{P}^{\prime}{ }_{\mathrm{Ca}} / \mathrm{P}_{\mathrm{Na}}\right)$ or $\mathrm{K}^{+}\left(\mathrm{P}_{\mathrm{Ca}} / \mathrm{P}_{\mathrm{K}}\right)$ were calculated from the shifts of the apparent reversal potential of the $\mathrm{Ca}^{2+}$ current induced by the addition of $\mathrm{Na}^{+}$or $\mathrm{K}^{+}$ to the extracellular solution, using a modified Goldman, Hodgkin and Katz equation (GHK) to take into account both divalent and monovalent ions. Thus, with a new $\mathrm{Ca}^{2+}$ permeability

$$
P_{C a}^{\prime}=\frac{P_{C a}}{1+\exp \left(\frac{F V}{R T}\right)}
$$

as described by Lewis [1], the apparent reversal potential $V_{0}$ of the current in the presence of both $\mathrm{Ca}^{2+}$ and a monovalent cation $\mathrm{X}^{+}$is given by the following equation:

$$
V_{o}=\frac{R T}{F} \log _{e} \frac{\left[X^{+}\right]_{o}+4\left(\frac{P^{\prime} C a}{P_{X}}\right)[C a]_{o}}{\left[X^{+}\right]_{i}+4\left(\frac{P_{C a}^{\prime} C a}{P_{X}}\right)[C a]_{i} \exp \left(\frac{F V_{o}}{R T}\right)}
$$

where [ion $]_{o}$ and [ion $]_{i}$ are the extracellular and intracellular ion activities, respectively, and $\mathrm{R}, \mathrm{T}$ and $\mathrm{F}$ have their usual meaning.

Since thermodynamic ion activity rather than concentration should be used in this equation and considering the ionic strength of the extracellular solution, activity coefficients of $\mathrm{Ca}^{2+}, \mathrm{Na}^{+}$and $\mathrm{K}^{+}$were calculated in each condition with the following Davies equation:

$$
\log _{10} \gamma_{i}=-0.509 z_{i}^{2} \frac{\sqrt{I}}{1+\sqrt{I}}-0.3 I
$$

with $\gamma_{i}$ and $z_{i}$ the activity coefficient and the valence of the ion $i$, respectively, and $\mathrm{I}$, the ionic strength of the extracellular solution.

From Eq. S4 and assuming that [Ca $]_{i}$ was negligible due to the presence of $10 \mathrm{mM}$ EGTA in the pipette solution and that $\left[\mathrm{X}^{+}\right]_{\mathrm{i}}$ due to $\mathrm{X}^{+}$influx remained constant when $\mathrm{X}^{+}$concentration was increased from concentration 1 to concentration 2, the relative permeability $\mathrm{P}_{\text {ca }}$ over $\mathrm{P}_{\mathrm{X}}$ can be calculated with the equation:

$$
\frac{P_{C a}^{\prime}}{P_{X}}=\frac{\left[X^{+}\right]_{o, 2} \exp \left(\frac{\Delta V_{r e v} F}{R T}\right)-\left[X^{+}\right]_{o, 1}}{4[C a]_{o}\left(1-\exp \left(\frac{\Delta V_{r e v} F}{R T}\right)\right)}
$$

Liquid junction potential was determined with the calculator provided in pClamp 9. Its variation due to solutions changes were less than $1 \mathrm{mV}$ (and also less than the error possibly made on the apparent current reversal determination) and were therefore ignored. 


\section{Supplementary Tables S1 and S2}

Table S1: Fast LVA channel selectivity in PVCM

\begin{tabular}{|c|c|c|c|c|c|c|c|}
\hline $\begin{array}{l}\text { Added monovalent } \\
\text { cation } \mathrm{X}^{+}\end{array}$ & $\begin{array}{l}\text { Acti } \\
\text { coefficier } \\
\mathrm{Ca}^{2+} \text { al }\end{array}$ & $\begin{array}{l}\text { vity } \\
\text { nts } \gamma \text { for } \\
\text { nd } x^{+}\end{array}$ & $\begin{array}{c}\text { Peak } \\
\text { amplitude } \\
(\mathrm{pA} / \mathrm{pF})\end{array}$ & $\begin{array}{l}\text { Apparent } \mathrm{V}_{\text {rev }} \\
(\mathrm{mV})\end{array}$ & $\begin{array}{l}\text { Measured } \\
\Delta V_{\text {rev }}(\mathrm{mV})\end{array}$ & $\begin{array}{l}\text { Theoretical } \\
\Delta V_{\text {rev }}(\mathrm{mV}) \\
\text { for only } \mathrm{X}^{+} \\
\text {permeation }\end{array}$ & $\begin{array}{c}\text { Relative } \\
\mathbf{P}_{\mathrm{Ca}} / \mathbf{P}_{\mathrm{X}} \text { for } \\
\text { bi-ionic } \\
\text { conditions }\end{array}$ \\
\hline \multicolumn{8}{|l|}{ Potassium K ${ }^{+}(n=7)$} \\
\hline Control $5 \mathrm{mM} \mathrm{CaCl}_{2}$ & 0.3271 & & $-1.42 \pm 0.32$ & $-22.70 \pm 2.74$ & & & \\
\hline$+5 \mathrm{mM} \mathrm{KCl}$ & 0.3246 & 0.7548 & $-6.47 \pm 1.21$ & $-14.78 \pm 1.47$ & $7.91 \pm 1.42$ & & $1.944 \pm 0.447$ \\
\hline$+10 \mathrm{mM} \mathrm{KCl}$ & 0.3223 & 0.7534 & $-9.56 \pm 1.59$ & $-8.92 \pm 1.76$ & $5.86 \pm 0.70$ & $17.8\left(25^{\circ} \mathrm{C}\right)$ & $1.812 \pm 0.299$ \\
\hline \multicolumn{8}{|l|}{ Sodium $\mathrm{Na}^{+}(\mathrm{n}=6)$} \\
\hline Control $5 \mathrm{mM} \mathrm{CaCl}_{2}$ & 0.3271 & & $-0.93 \pm 0.29$ & $-15.99 \pm 0.85$ & & & \\
\hline$+1 \mathrm{mM} \mathrm{NaCl}$ & 0.3266 & 0.7560 & $-5.13 \pm 0.81$ & $-12.03 \pm 0.86$ & $4.83 \pm 1.38$ & & $2.254 \pm 0.508$ \\
\hline$+3 \mathrm{mM} \mathrm{NaCl}$ & 0.3256 & 0.7554 & $-14.35 \pm 1.63$ & $1.33 \pm 1.39$ & $13.62 \pm 1.10$ & 28. $2\left(25^{\circ} \mathrm{C}\right)$ & $0.223 \pm 0.033$ \\
\hline
\end{tabular}

$\mathrm{V}_{\text {rev }}$ : current reversal potential. $\mathrm{P}^{\prime}{ }_{\mathrm{ca}} / \mathrm{P}_{\mathrm{x}}$ : relative permeabilty of $\mathrm{Ca}^{2+}$ over cation $\mathrm{X}^{+}$. lonic strength I of the extracellular recording solution was $0.162 \mathrm{~mol} / \mathrm{L}$ in $5 \mathrm{mM} \mathrm{CaCl}_{2}$ control conditions. With $1,3,5$ and $10 \mathrm{mM}$ added $\mathrm{XCl}$ (with $\mathrm{X}$ representing $\mathrm{Na}^{+}$or $\mathrm{K}^{+}$), I increased to $0.163,0.165,0.167$ and 0.172 $\mathrm{mol} / \mathrm{L}$, respectively.

Table S2: Pharmacology of PVCM fast LVA current

\begin{tabular}{|c|c|c|c|c|}
\hline Test compounds & & Control (pA/pF) & Compound $(\mathrm{pA} / \mathrm{pF})$ & $P$ \\
\hline Nifedipine & $5 \mu \mathrm{M}, \mathrm{n}=5$ & $-5.28 \pm 0.69$ & $-2.96 \pm 0.32$ & 0.014 \\
\hline (士) BayK 8644 & $300 \mathrm{nM}, \mathrm{n}=6$ & $-1.71 \pm 0.55$ & $-3.31 \pm 0.42$ & 0.046 \\
\hline Norepinephrine & $10 \mu \mathrm{M}, \mathrm{n}=13$ & $-0.427 \pm 0.096$ & $-1.036 \pm 0.120$ & $<0.001$ \\
\hline Ranolazine & $10 \mu \mathrm{M}, \mathrm{n}=6$ & $-0.994 \pm 0.124$ & $-1.017 \pm 0.112$ & 0.0675 \\
\hline \multirow[t]{2}{*}{ TTA-A2 } & $10 \mathrm{nM}, \mathrm{n}=11$ & $-0.293 \pm 0.059$ & $-0.434 \pm 0.064$ & 0.006 \\
\hline & $100 \mathrm{nM}, \mathrm{n}=6$ & $-0.226 \pm 0.044$ & $-0.523 \pm 0.090$ & 0.019 \\
\hline $\mathrm{NiCl}_{2}$ & $40 \mu \mathrm{M}, \mathrm{n}=9$ & $-0.123 \pm 0.026$ & $-0.486 \pm 0.176$ & 0.039 \\
\hline
\end{tabular}

Control current was recorded in the presence of either 2 or $5 \mathrm{mM} \mathrm{CaCl}_{2} .5 \mathrm{mM} \mathrm{KCl}$ was added to the solution for Nifedipine and BayK experiments to increase the current amplitude. Current amplitudes correspond to the maximum peak current. $P$ values for paired $t$-test except last compound (MannWhitney Rank Sum test) 


\section{Supplementary figures S1 to S6}
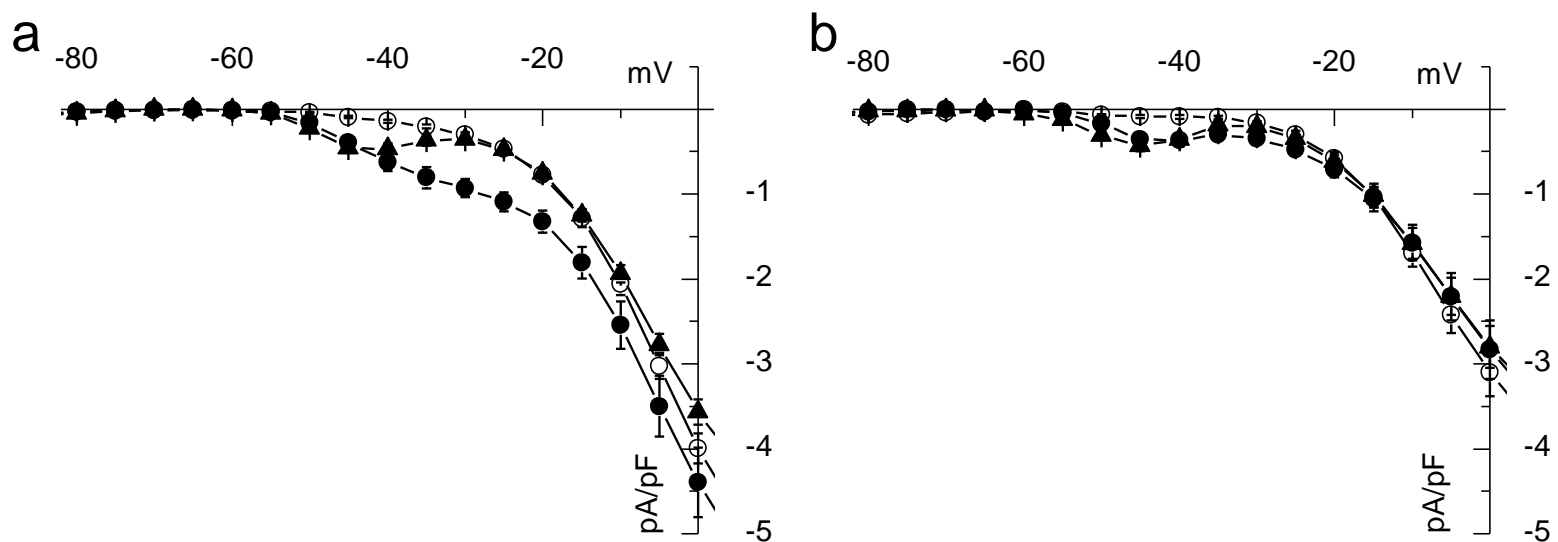

Fig S1 Low voltage activated (LVA) $\mathrm{Ca}^{2+}$ currents from $-100 \mathrm{mV}$ in PVCM and LACM in the presence of $2 \mathrm{mM} \mathrm{Ca}^{2+}$.

a, Mean current voltage (IV) relationships of the fast activating and inactivating (FLVA) current ( $\mathbf{\Delta}$, $\mathrm{n}=63$ ), slow activating and inactivating current (SLVA; $O, n=43$ ) and fast activating and slow inactivating current (FSLVA; $\bullet, n=21$ ) in PVCM. b, same as a, but for $\operatorname{LACM}(O, n=29 ; \boldsymbol{\Delta}, n=33$; $n=11$. Data points are mean \pm SE of $n$ PVCM or LACM.
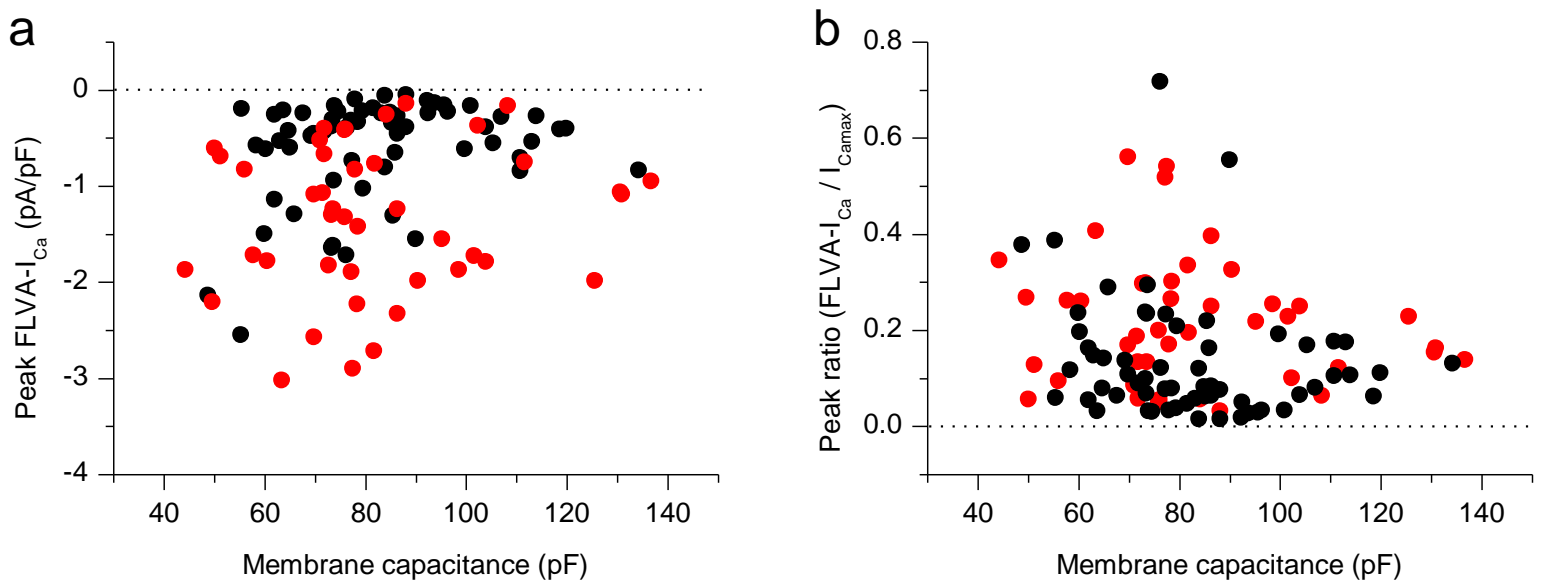

Fig S2: Peak FLVA-I $\mathrm{Ca}_{\mathrm{C}}$ in rat PVCM vs. CM size.

Peak FLVA-I $\mathrm{C}_{\mathrm{C}}$ does not depend on the CM size approximated by the membrane capacitance (a), as well as its ratio to maximum peak $I_{C a}, I_{C a m a x}(b)$, either in the presence of $2 \mathrm{mM}$ (black symbols) or 5 $\mathrm{mM}$ (red symbols) $\mathrm{Ca}^{2+}$. 


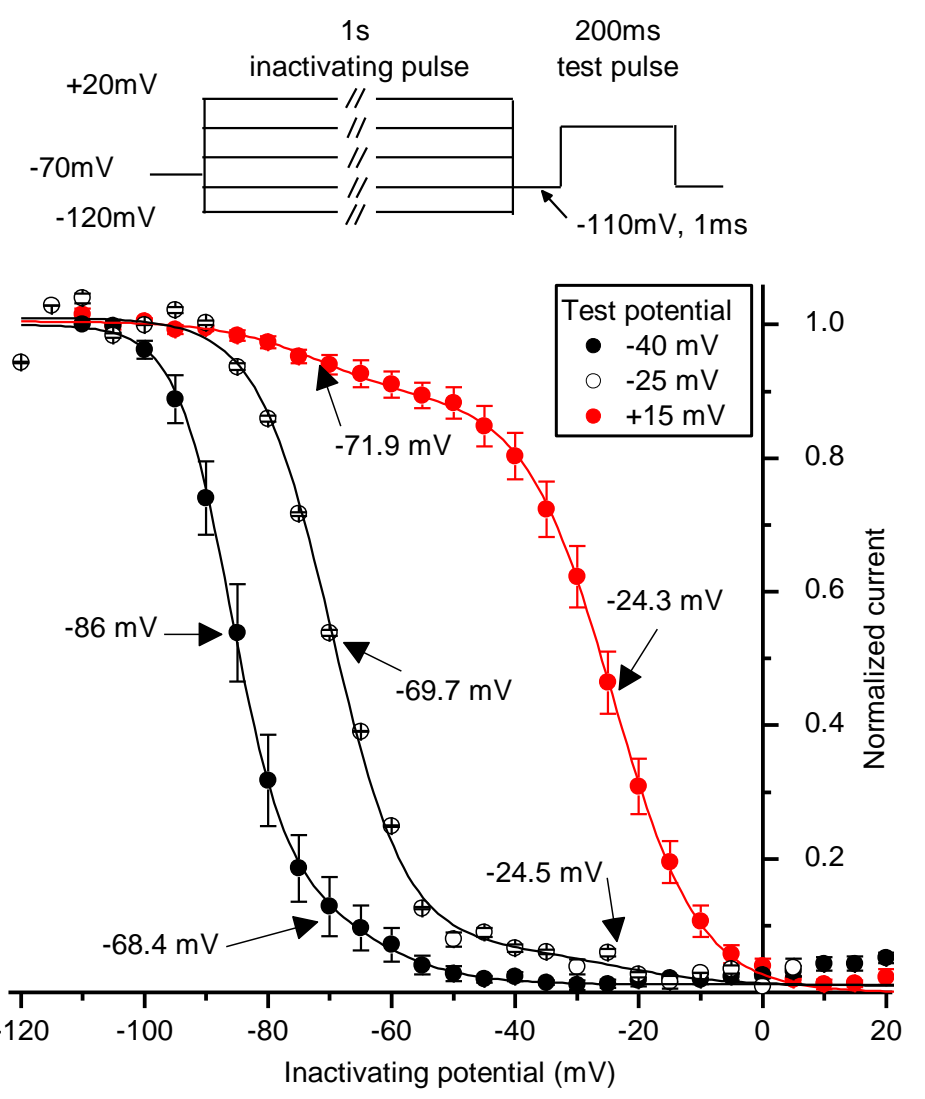

Fig. S3: Steady-state availability of the $\mathrm{Ca}^{2+}$ current recorded at three different test potentials in PVCM. The protocol used is shown on the upper part of the figure. Test potentials correspond to nearly maximum FLVA current $(-40 \mathrm{mV}, \mathrm{n}=6)$, apparent reversal potential of FLVA current and prominent shoulder of the current-voltage relationship $(-25 \mathrm{mV}, \mathrm{n}=4$ - see Fig. S6) and maximum peak $I_{C a}$ current $(+15 \mathrm{mV}, \mathrm{n}=10)$. Smooth lines represent fit to the mean data points of double Boltzmann equations with respective half-voltage of inactivation $V_{0.5}$ indicated near each curve. 


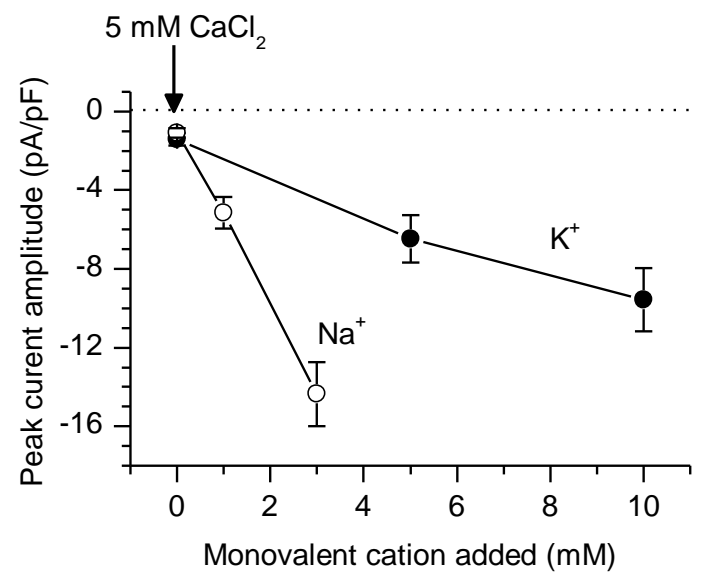

Fig. S4: Increase of peak current FLVA current upon the addition of $\mathrm{Na}^{+}$or $\mathrm{K}^{+}$. Data points are mean values $\pm \mathrm{SE}$ obtained in $6\left(\mathrm{Na}^{+}\right)$or $8\left(\mathrm{~K}^{+}\right)$ CM. Same cells as figures 4 and 5 .
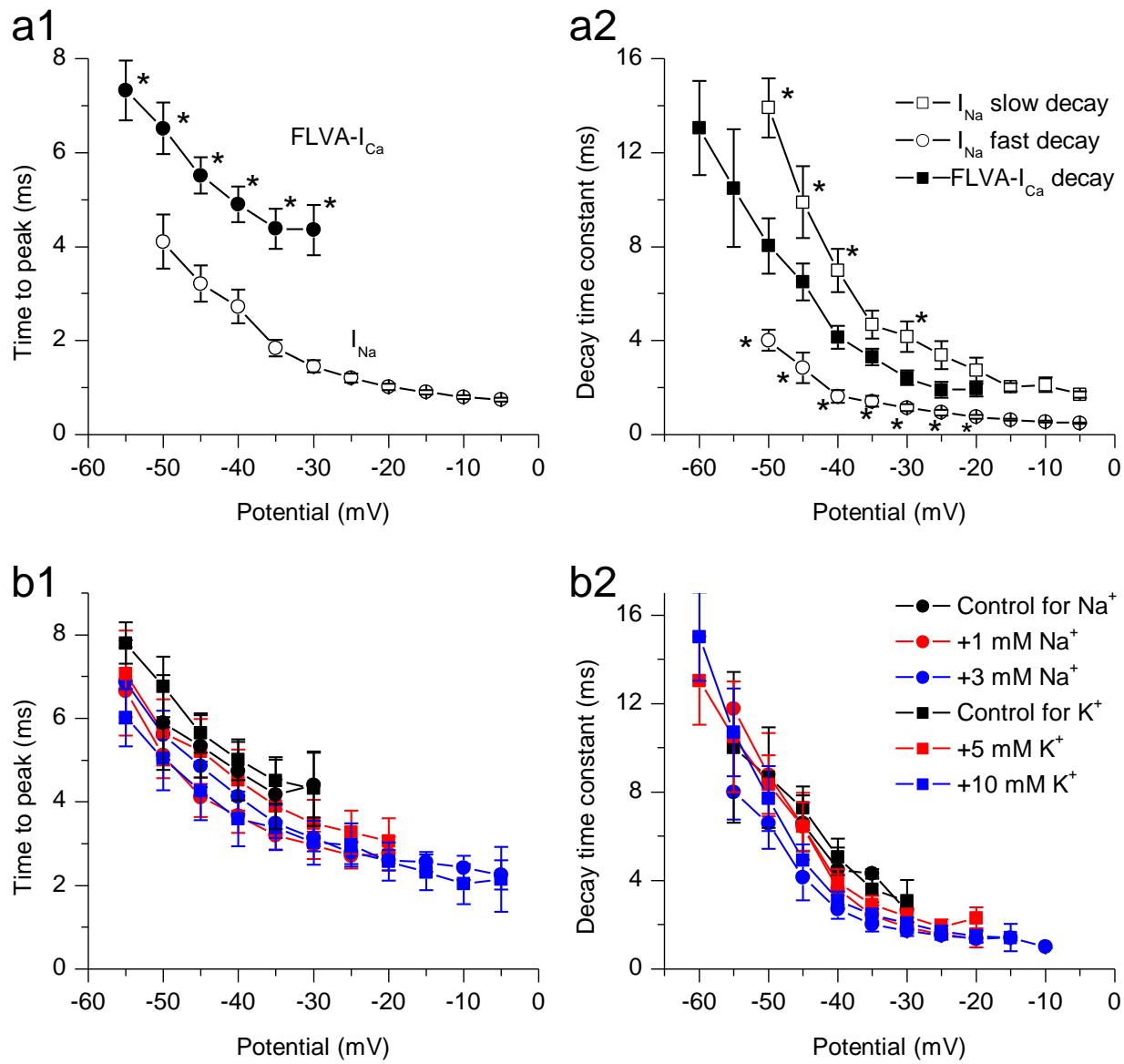

Fig. S5. Kinetics of activation and inactivation of the fast $\mathrm{Na}\left(\mathrm{I}_{\mathrm{Na}}\right)$ and FLVA currents.

Time to peak (a1) and inactivation time constants (a2) voltage relationships of the fast $\mathrm{Na}\left(\mathrm{I}_{\mathrm{Na}}\right)$ and FLVA currents recorded in the presence of $5 \mathrm{mM} \mathrm{Ca}^{2+}$. Data are mean values $\pm S E\left(I_{\mathrm{Na}}: n=12 ; \mathrm{FLAV}-\mathrm{I}_{\mathrm{Ca}}\right.$ : $n=14) .\left({ }^{*}\right)$ denote statistical difference between $I_{\mathrm{Na}}$ and FLVA current (Mann-Whitney rank sum test or Student's $t$-test where appropriate). Time to peak (b1) and inactivation time constants (b2) voltage relationships of the FLVA current in control conditions $\left(5 \mathrm{mM} \mathrm{Ca}^{2+}\right)$ and in the additional presence of $\mathrm{Na}^{+}(\mathrm{n}=6)$ or $\mathrm{K}^{+}(\mathrm{n}=8)$. 


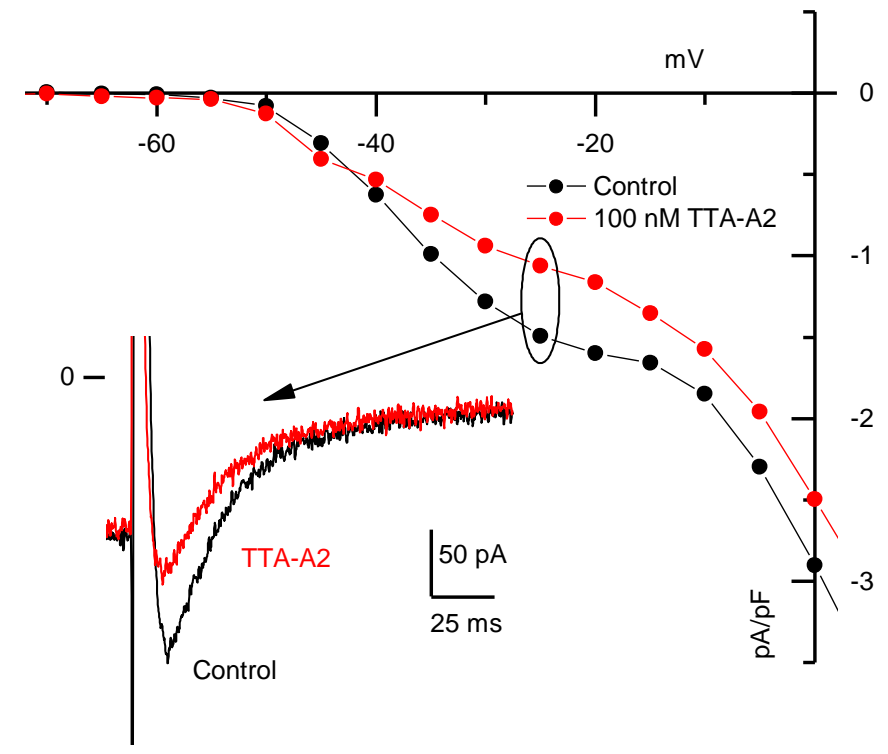

Fig S6: Presence of a TTA-A2-sensitive current in PVCM.

$100 \mathrm{nM}$ TTA-A2 significantly reduced the current amplitude recorded at $-25 \mathrm{mV}$. Note that the prominent shoulder in the current-voltage relationship has not entirely disappeared at this concentration.

\section{References}

1. Lewis CA (1979). Ion-concentration dependence of the reversal potential and the single channel conductance of ion channels at the frog neuromuscular junction. J Physiol. 286:417445 .

doi: 10.1113/jphysiol.1979.sp012629. PMID: 312319

2. Malécot CO, Bredeloux $\mathrm{P}$, Findlay I, Maupoil V. A TTX-sensitive resting $\mathrm{Na}^{+}$permeability contributes to the catecholaminergic automatic activity in rat pulmonary vein. J Cardiovasc Electrophysiol. 2015;26:311-319. doi: 10.1111/jce.12572. PMID : 25346483

3. Pasqualin C, Yu A, Malécot CO, Gannier F, Cognard C, Godin-Ribuot D, Morand J, Bredeloux P, Maupoil V. Structural heterogeneity of the rat pulmonary vein myocardium: consequences on intracellular calcium dynamics and arrhythmogenic potential. Sci Rep. 2018; 8:3244. doi: 10.1038/s41598-018-21671-9. PMID: 29459735 